\title{
Cell shrinkage and apoptosis: a role for potassium and sodium ion efflux
}

\author{
Justin V. McCarthy ${ }^{1}$ and Thomas G. Cotter ${ }^{1,2}$ \\ ${ }^{1}$ Tumour Biology Laboratory, Department of Biochemistry, Lee Maltings, \\ Prospect Row, University College Cork, Cork, Ireland \\ 2 corresponding author: Prof. T.G. Cotter, Tumour Biology Laboratory, \\ Department of Biochemistry, Lee Maltings, Prospect Row, University College \\ Cork, Cork, Ireland. tel: +353-21-276871; fax: +353-21-274034; \\ e-mail: t.cotter@ucc.ie
}

Received 27.1.97; revised 2.7.97; accepted 7.7.97

Edited by M. Piacentini

\begin{abstract}
In this study we have shown that redistribution of the lipid composition of the external and internal leaflets of the PM during apoptosis results in two main alterations in the cell surface, externalisation of PS, and a looser packing of the lipid hydrophobic head groups in the external leaflet. Significantly, neither of these alterations can be directly implicated in the mechanism of apoptotic cell shrinkage, however they do have functions in other phases of the apoptotic process. Progressional studies involving morphological and flow cytometric evaluation, and DNA gel electrophoresis revealed that apoptotic cell shrinkage is associated with a decrease in $\left[\mathrm{Na}^{+}\right]_{\mathrm{i}}$ and $\left[\mathrm{K}^{+}\right]_{\mathrm{i}}$ which occurs after visualisation of chromatin condensation and internucleosomal DNA fragmentation, and prior to apoptotic body formation. When apoptotic cultures were supplemented with inhibitors of the $\mathrm{Na}^{+}, \mathrm{K}^{+}$-ATPase pump or the $\mathrm{Ca}^{2+}$-dependent $\mathrm{K}^{+}$channel, essentially all of the respective $\mathrm{Na}^{+}$or $\mathrm{K}^{+}$efflux during apoptosis can be inhibited, suggesting that essentially all of the $\mathrm{Na}^{+}$and $\mathrm{K}^{+}$efflux can be ascribed to active pumping via the $\mathrm{Na}^{+}, \mathrm{K}^{+}$-ATPase pump and the $\mathrm{Ca}^{2+}$-dependent $\mathrm{K}^{+}$channel.
\end{abstract}

Keywords: apoptosis; cell shrinkage; HL-60; sodium; potassium; $\mathrm{Na}^{+} / \mathrm{K}^{+}$-ATPase; $\mathrm{Ca}^{2+}$-dependent potassium channel

Abbreviations: UV, ultra-violet; $\left[\mathrm{Na}^{+}\right]_{\mathrm{i}},\left[\mathrm{K}^{+}\right]_{\mathrm{i}}$, intracellular free sodium and potassium concentrations, respectively. FSC, forward light scatter; SSC, side light scatter; MC540, Merocyanine 540; PBFI, Potassium binding benzofuran isophthalate; PM, plasma membrane, PS, phosphatidylserine; RVD, Regulatory volume decrease; SEM, standard error of the mean; TPA, tetra-pentyl ammonium; HBSS, Hank's balanced salt solution; DMEM, Dulbecco's modified eagle medium

\section{Introduction}

The realisation that active or physiological cell death is a common biological phenomenon distinguishable from necrosis (Kerr et al, 1972; Wyllie, 1987, 1993) has had a profound impact on investigations into cell death and our understanding of embryonic development and tissue homeostasis. The most common and best described form of this type of cell death (programmed cell death) is apoptosis (Kerr et al, 1972), which can occur either from developmentally controlled activation of an endogenous suicide programme (Ellis et al, 1991; Kerr et al, 1974; Lockshin et al, 1991) or from transduction of death signals triggered by a wide variety of exogenous stimuli (Lennon et al, 1991; Kizali et al, 1988; ljiri et al, 1987; Bonyhadi et al, 1993). Subsequent to the transduction of an apoptosis inducing signal, mammalian cells, as well as other cell types, initiate a cascade of both morphological and biochemical changes which have been the basis of intensive research in recent years (reviewed in Raff, 1992; Zakeri et al, 1995; Martin et al, 1995).

Alterations in cell volume and granularity appear to be universal characteristics of apoptosis observed in in vitro cell lines (Martin et al, 1990; Shi et al, 1992), thymocytes (Wyllie and Morris, 1982) peripheral blood neutrophils (Savill et al, 1983) and eosinophils, with a loss of up to $30 \%$ of the cell volume being observed in neutrophils (Beauvais et al, 1995) and thymocytes (Ohyama et al, 1986; Thomas and Bell, 1981), and up to $60 \%$ in eosinophils (Beauvais et al, 1995) undergoing apoptosis. Shrinkage of cells during apoptosis has been attributed to the net movement of fluid out of the cell. A possible mechanism to account for this displacement of water during apoptotic cell shrinkage has been suggested to involve the fusion of internal fluid filled membrane bound vesicles, probably of golgi or smooth endoplasmic reticulum origin, with the plasma membrane (Morris et al, 1984; Cohen et al, 1992). On fusion with the PM the vesicles release their contents into the extracellular space resulting in apoptotic cell shrinkage and perhaps also accounting for the pitted appearance of the apoptotic cell surface (Yamada and Ohyama, 1988). However, despite its universal occurrence and importance in the apoptotic process, the regulation and function of this cytoplasmic condensation associated with apoptosis is poorly understood and its significance has not been validated.

The primary determinant of cell volume is water content, which accounts for approximately $70 \%$ of total cell mass. In animal cells, which lack mechanically resistant cell walls, the control of cell volume is largely dependent on the cellular control of osmotically active particles, the largest component being inorganic ions, $\mathrm{K}^{+}, \mathrm{Cl}^{-}$and $\mathrm{Na}^{+}$being the most abundant species (Lichtman et al, 1972; Negendank, 1982). Under physiological conditions, the regulation of cell volume is of importance to most cell types and therefore, cells possess a diverse repertoire of ion channels and pumps through which ion gradients, particularly $\mathrm{K}^{+}, \mathrm{Cl}^{-}$ and $\mathrm{Na}^{+}$, are maintained, thereby establishing a relatively constant cell volume (Hoffmann and Simonsen, 1989; Lande et al, 1995). When cells are exposed to conditions outside of normal physiological conditions, i.e. anisotonic 
media, the cell initially behaves as an osmometer, undergoing volume changes dictated by a passive water flow across the cell membrane. In a hypotonic environment many cell types after initially swelling, undergo a slower, compensatory shrinkage through the loss of intracellular solutes along with osmotically obligated water, a process known as regulatory volume decrease (RVD), which returns the cell to a near physiological volume (Hoffmann and Simonsen, 1989; Lande et al., 1995; Grinstein et al., 1984; Hoffmann, 1985). Although a wide variety of cells can regulate their volume, there is a wide diversity in the ion transport systems involved (Hoffmann and Simonsen, 1989; Lande et al, 1995; Grinstein et al, 1984; Hoffmann, 1985; Gallin, 1991). HL-60 cells, following hypotonic stress can undergo RVD (Hallow et al, 1991). The ion transport pathways involved for HL-60 RVD appear to be similar to those described by Grinstein et al. (1984) for lymphocytes, whereby RVD is mediated through the efflux of $\mathrm{K}^{+}$and $\mathrm{Cl}^{-}$ ions through separate membrane channels (Hallow et al, 1991). Similarly, ions such as $\mathrm{Na}^{+}, \mathrm{K}^{+}$and $\mathrm{H}^{+}$are involved in fibroblast volume regulation (Woll et al, 1993).

Because cells possess such a vast repertoire of volume regulatory mechanisms, and can induce cell shrinkage when physiological conditions are unfavourable, in this study we sought to determine whether regulated cell shrinkage accompanying apoptosis was preceded or accompanied by alterations in the plasma membranes permeability to certain ions, or involved alterations in ion gradients. The recent development of selective ionic indicators for the fluorometric determination of specific ion concentrations with sufficient selectivity in the presence of physiological concentrations of other ions, has provided a non-invasive technique for determining intracellular free ion concentrations. Furthermore, by exploiting the characteristics of other cell specific cell surface probes, i.e. annexin V-FITC, which preferentially binds to phosphatidylserine and merocyanine 540 (Williamson et al, 1983; Collins et al, 1977; Dalton et al, 1988; Martin and Cotter, 1991; Gorman et al, 1996) which selectively stains loosely packed lipid membranes, we are provided with convenient tools to directly measure cellular changes associated with apoptosis and to measure these changes on a single cell basis. Importantly, because of increasing evidence suggesting normal genetic regulators of cell proliferation and differentiation as regulators of apoptosis (Martin and Green, 1995), a parallel mechanism may be involved in the physiological regulators of cell volume, whereby ion transport mechanisms normally associated with the maintenance of cell volume, may also be involved in the regulation of apoptotic cell shrinkage.

Here we have shown that HL-60 apoptosis associated cell shrinkage, induced by UV-irradiation, is paralleled by an efflux of $\mathrm{Na}^{+}$and $\mathrm{K}^{+}$ions, as assessed by the decreased Sodium Green ${ }^{\mathrm{TM}}$ and PBFI binding properties of these cells. Furthermore, $\mathrm{Na}^{+}$and $\mathrm{K}^{+}$efflux during apoptotic cell shrinkage is reduced following inhibition of the $\mathrm{Na}^{+}, \mathrm{K}^{+}$-ATPase and $\mathrm{Ca}^{2+}$-dependent potassium channels, respectively. Importantly, inhibition of the $\mathrm{Na}^{+}$, and $\mathrm{K}^{+}$efflux prevents apoptotic cell shrinkage and subsequent apoptotic body formation, occurring indepen- dently of both chromatin condensation and internucleosomal DNA fragmentation. Together these observations provide evidence that apoptotic cell shrinkage is mediated through an active efflux of sodium and potassium ions. Assessment of plasma membrane lipid redistribution and lipid packing revealed that cell shrinkage was preceded by phosphatdylserine (PS) externalisation and occurred concomitant with a decrease in plasma membrane lipid packing.

\section{Results}

\section{Apoptosis associated cell shrinkage in HL-60 cells}

This study involved the assessment and quantification of apoptotic HL-60 cell shrinkage, therefore, initially the characteristics of apoptotic cell shrinkage were defined and alterations in the membrane fluidity and permeability during apoptosis were determined. As in previous reports (Lennon et al, 1991; Martin and Cotter, 1991), when exponentially growing HL-60 cell cultures were exposed to cytotoxic agents or UV irradiation virtually all cells undergo apoptosis, displaying typical apoptotic morphologies and characteristics, including cytoplasmic condensation, cell shrinkage and apoptotic body formation (Figure 1A). These changes can be readily detected in most cells by their light scattering properties on a flow cytometer (Figure 1B), where changes in cell volume are thought to be the consequence of extrusion of water from the cell in early apoptosis, prior to apoptotic body formation. In this type of analysis apoptotic cells are observed to decrease in FSC (cell size) and increase in granularity (SSC) (Figure 1B arrow), which is consistent with the idea that these cells condense in size due to the extrusion of water rather than due to leakage of cellular contents. This apoptotic population disappears when a sub-population of apoptotic bodies becomes prominent with very low FSC and SSC (Figure 1B). In the experiment described (Figure 1B) it is clear that the HL-60 cell population was transformed into a shrunken apoptotic population without any apparent intermediate cell sizes, indicating that apoptosis associated cell shrinkage is a very rapid process. This is validated by the detection of only three populations, normal, shrunken apoptotic cells and apoptotic bodies (Figure 1B).

\section{Apoptosis in HL-60 cells involves a decrease in membrane lipid packing}

The dramatic changes associated with cell shrinkage and apoptotic body formation suggests a role for the cytoskeleton and ion fluxes in the apoptotic process. Several workers have shown that changes in the cytoskeleton (Cotter et al, 1992; Martin and Cotter, 1991; Lockshin and Zakeri-Milovanovic, 1994) and lipid asymmetry of the membrane bi-layer accompany apoptotic cell death (Savill et al, 1989; Fadok et al, 1992a,b, 1993). By increasing the fluidity of its membrane, a coincident increase in permeability to various ions i.e. $\mathrm{K}^{+}$, $\mathrm{Na}^{+}$or $\mathrm{Cl}^{-}$, known to determine cell volume, may initiate a subsequent cell shrinkage in an apoptotic cell. However, little data is available where membrane fluidity and the permeability properties of membranes are compared, and it is 
unclear whether membrane fluidity determines permeability to certain cellular constituents. This study investigated whether alterations in the lipid composition of the external leaflet altered the membranes fluidity or permeability sufficiently to accommodate cell shrinkage.

A
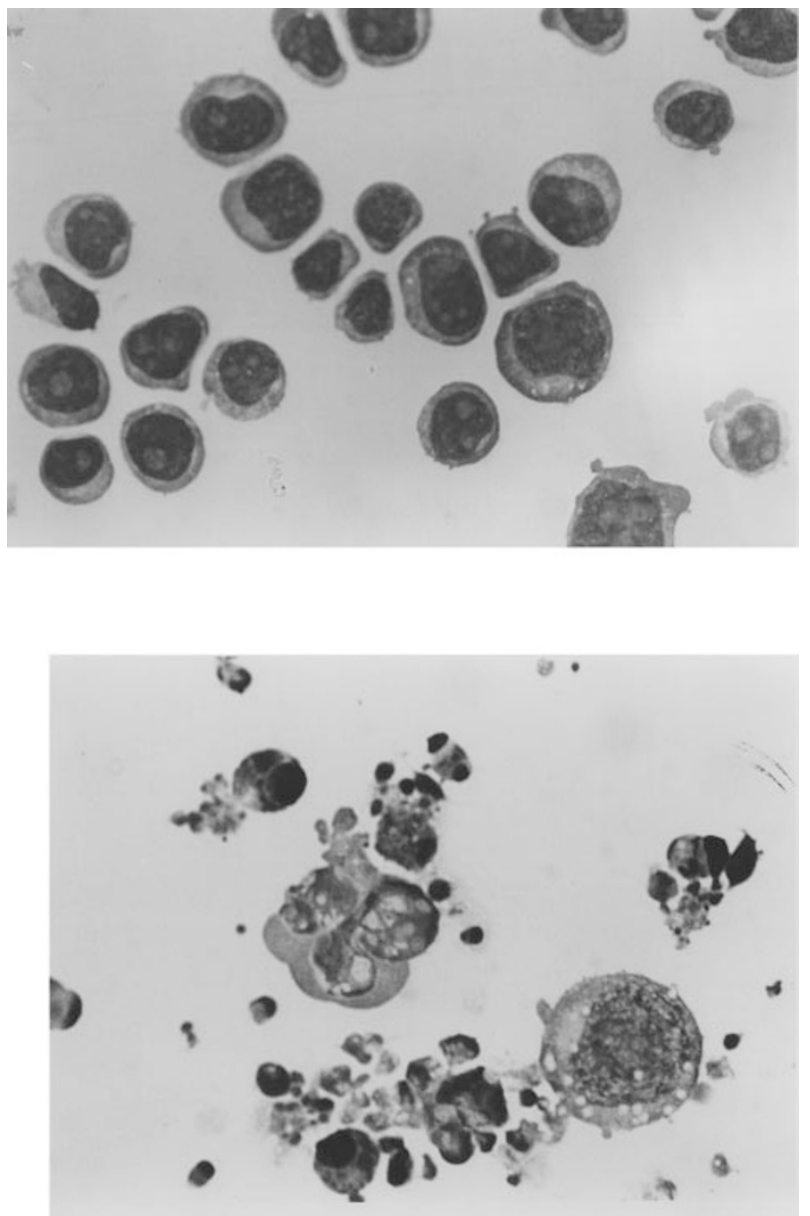

B

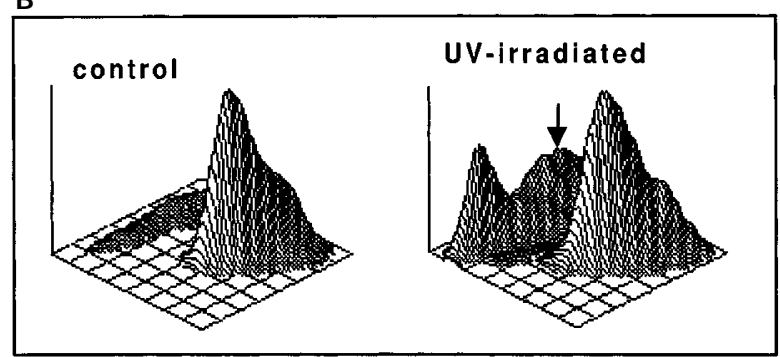

Figure 1 Induction of apoptosis by UV-irradiation in HL-60 cell cultures. (A) The morphologies of exponentially growing cells under standard conditions and cells UV-irradiated for $10 \mathrm{~min}$ and subsequently cultured for $2 \mathrm{~h}$ are shown. Typical apoptotic features displayed by irradiated cells include cell shrinkage, chromatin condensation and apoptotic body formation. Magnification $\times 400$. (B) A 3-dimensional plot of untreated and UV-irradiated cells. In each case forward scatter (cell size) is plotted against side scatter. Note the appearance of an apoptotic cell peak, and larger apoptotic body subpopulation typified by a further reduction in cell size and granularity in UV-irradiated cells
Apoptosis in HL-60 cells is associated with a redistribution in the lipid composition of the plasma membrane lipid bi-layer (Figure 2A), resulting in a time dependentexternalisation of PS which is normally restricted to the inner leaflet of the membrane (Martin et al, 1995; Op den Camp, 1979). PS is an unsaturated fatty acid and a determinant of the fluidity of biological membranes, therefore externalisation of PS during apoptosis from the inner to the outer leaflet of the membrane bi-layer would naturally increase the fluidity of the cells plasma membrane. Therefore, it is possible that the appearance of cells with

A

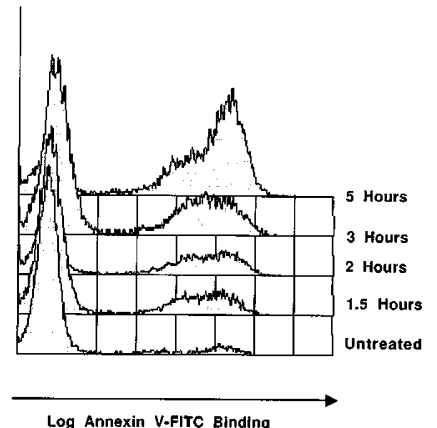

B

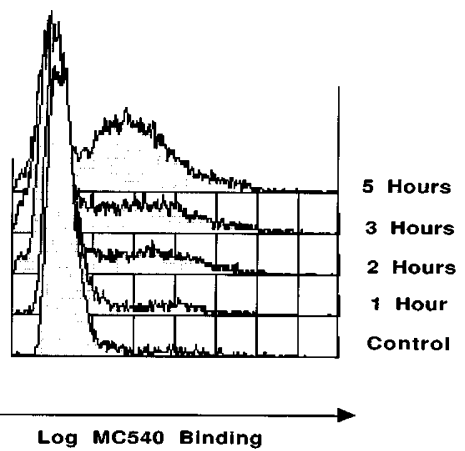

C

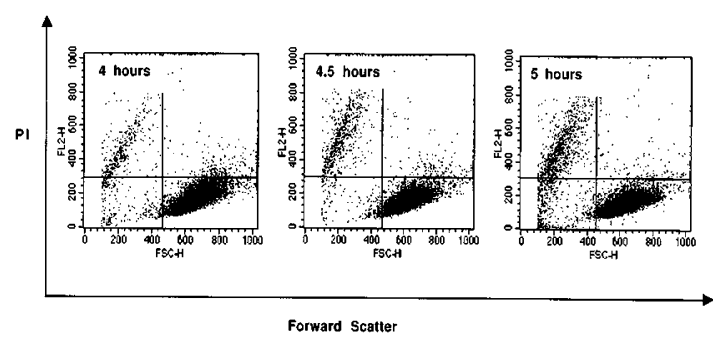

Figure 2 Alterations in plasma membrane lipid distribution and packing during HL-60 apoptosis induced by UV-irradiation. (A) Exponentially growing HL-60 cells were UV-irradiated for 10 min after which a time course of PS externalisation was initiated and assessed by the binding of annexin V-FITC. (B) Exponentially growing HL-60 cells were UV-irradiated for $10 \mathrm{~min}$, after the indicated times lipid packing was assessed by the binding of merocyanine 540 . (C) HL-60 cell cultures were induced to undergo apoptosis following UVirradiation for $10 \mathrm{~min}$. Membrane permeability was determined by propidium iodide staining at the indicated time points by flow cytometry. Annexin V-FITC, Merocyanine 540 and propidium iodide binding was assessed in parallel samples by flow cytometry as detailed in Materials and Methods. 10000 cells were analysed in each condition and the results illustrated are representative of typical experiments 
externalised PS may coincide with the appearance of cells with fluid membranes in these cultures, allowing an increase in the cells permeability to various volume regulatory ions. Initially alterations in lipid packing were determined by staining cells with the naturally fluorescent liphophylic dye, merocyanine 540 (MC540), which selectively stains disordered or loosely packed membranes (Williamson et al, 1983; McEvoy et al, 1988). Irradiated HL-60 were stained with MC540 to detect changes in lipid distribution at various times thereafter. As shown in Figure $2 \mathrm{~B}$, before irradiation only one population was detected which displayed low MC540 binding. However, similar to annexin V-binding, $2 \mathrm{~h}$ post-irradiation a population of cells with increased MC540 binding began to emerge and rapidly increased in a time dependent manner. It is unlikely that this altered lipid packing is associated with increasing the membranes permeability to accomodate cell shrinkage, since increases in membrane permeability normally occur late during the apoptotic process (McGahon et al, 1995; Gorman et al, 1996). However to exclude this possibility, irradiated HL-60 cells were stained with propidium iodide dye, to reveal cells with damaged membranes. In parallel with the PI staining a separate cell sample was stained with MC540 to determine if decreased lipid packing coincided with membrane damage. This experiment (Figure 2C) demonstrated that a population of cells with high MC540 binding was detected well in advance of any increase in $\mathrm{PI}$ binding and cell permeability, thus implying that the observed decrease in lipid packing is not associated with the membrane permeability but rather to cell shrinkage and the externalisation of PS an un-saturated fatty acid which would naturally decrease the packing of a membrane.

To determine whether the apoptosis-associated changes in the plasma membrane lipid packing occurred coincident with or before the morphological features of apoptosis, HL60 cells were induced to undergo apoptosis by UVirradiation, and the appearance of cells with reduced cell volumes was evaluated by flow cytometry. At each time point the proportion of MC540 binding cells was simultaneously determined by flow cytometry. As shown in Figure 3A, MC540 positive cells in irradiated cultures were found in abundance in cells that had undergone cell shrinkage. This observation is validated by the fact that no MC540 positive cells were observed in irradiated populations which had not yet undergone cell shrinkage (Figure $3 \mathrm{~A}$ lower panels). Furthermore, using another characteristic of apoptosis, DNA fragmentation, MC540 positive cells were also found in abundance in populations which had not yet fragmented their DNA (Figure 3B). Taken together these data suggest that decreased lipid packing precedes
A
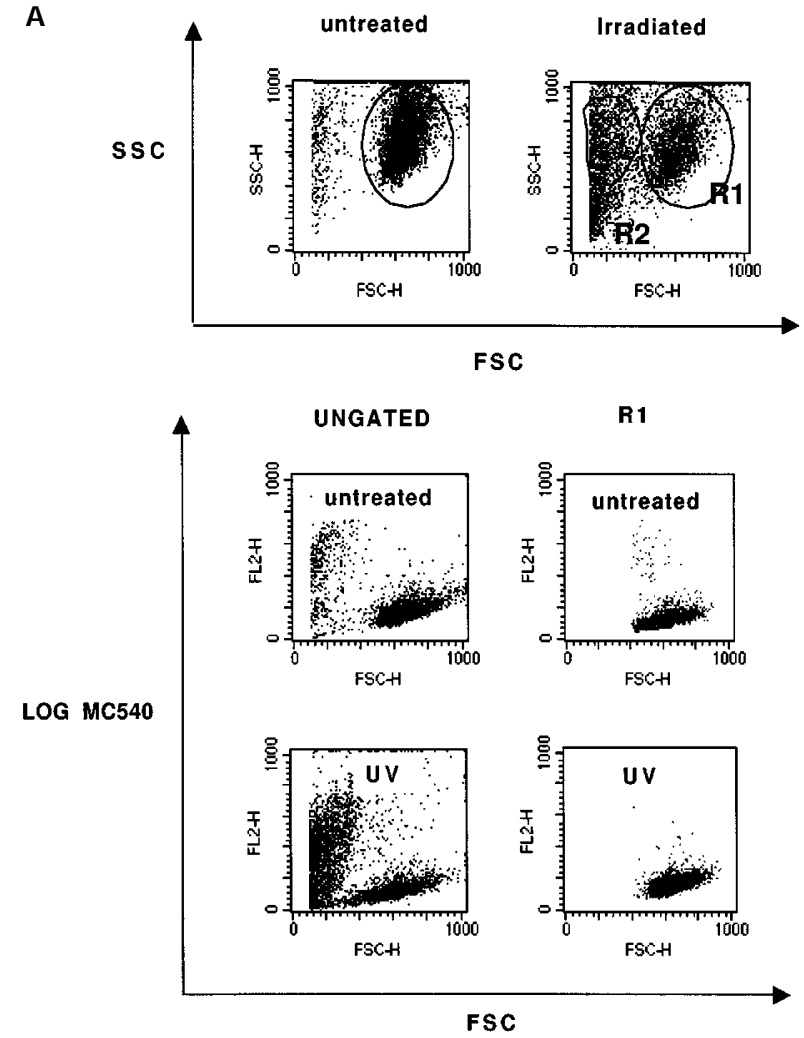

B

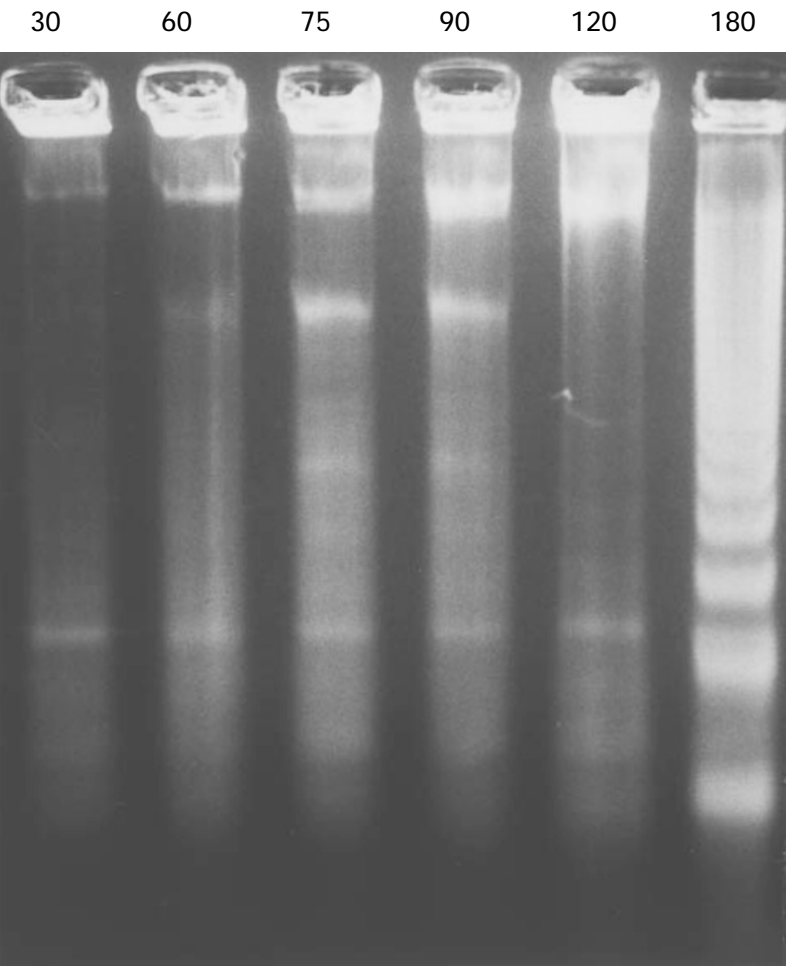

Figure 3 Decreased membrane lipid packing coincides with cell shrinkage and precedes internucleosomal DNA fragmentation of apoptotic HL-60 cells. (A) Detection of increased MC540 binding in irradiated cells coincides with cell shrinkage as assessed by changes in the light scattering properties of the cells, following UV-irradiation. HL-60 cells were either left untreated (upper panels) or UV-irradiated (lower panels) for $10 \mathrm{~min}$ and subsequently cultured for $2 \mathrm{~h}$. Apoptotic cells (R2) were distinguished from viable cells (R1) on the basis of their light scattering properties. 10000 cells were analysed in each situation. (B) Detection of internucleosomal DNA fragmentation in UV-irradiated HL-60 cell at the indicated time points (30,60, $75,90,120$, and 180 min post-irradiation) by agarose gel electrophoresis 
internucleosomal DNA fragmentation and is observed predominantly in shrunken cells.

It has been speculated that cell shrinkage during apoptosis results from the extrusion of water in fluid filled vesicles, arising from the endoplasmic reticulum or golgi apparatus, which fuse with the plasma membrane and release their watery contents into the extracellular space (Yamada and Ohyama, 1988; Morris et al, 1984; Cohen et al, 1992; Galili et al, 1982). Normally, under physiological conditions, cell volume homeostasis is maintained by the interactive functioning of plasma membrane associated ion channels and pumps (Lichtman et al, 1972; Roti-Roti and Rothstein, 1973; Hoffmann and Simonsen, 1939; Lande et al, 1995; Grinstein et al, 1984; Hoffmann, 1985; Gallin, 1991). It seems unlikely that a cell would possess a number of volume regulatory devices and not use them during apoptosis when cytoplasmic condensation and fragmentation are desired. It was on the basis of this proposal that this study proceeded, by investigating some of the main volume regulatory pumps, channels and ions involved in the regulation of cell volume, to determine whether they had a role as positive regulators of apoptotic cell shrinkage.

\section{Inhibition of the $\mathrm{Na}^{+}, \mathrm{K}^{+}$-ATPase pump prevents apoptotic cell shrinkage and subsequent apoptotic body formation}

The ouabain inhabitable $\mathrm{Na}^{+}, \mathrm{K}^{+}$-ATPase enzyme is responsible for the active transport of $\mathrm{Na}^{+}$and $\mathrm{K}^{+}$ions across the plasma membrane and is also involved in the regulation of cell volume in most animal cells (Glynn, 1985). Because of these observations it was decided to investigate a potential role for the $\mathrm{Na}^{+}, \mathrm{K}^{+}$-ATPase enzyme in apoptosis mediated cell shrinkage. HL-60 cell cultures which were supplemented with ouabain for cell volume studies were induced to undergo apoptosis when UV-irradiated for $10 \mathrm{~min}$ and subsequently cultured for $2 \mathrm{~h}$. From flow-cytometric analysis, it was determined that inhibition of the ouabainsensitive $\mathrm{Na}^{+}, \mathrm{K}^{+}$-ATPase resulted in a decrease in the number of apoptotic cells exhibiting a reduced cell volume and in the frequency of subsequent apoptotic body formation (Figure 4A). To further investigate this phenomenon, apoptotic HL-60 cell cultures were supplemented with concentrations of ouabain ranging from $3-800 \mu \mathrm{M}$ for a period of $3 \mathrm{~h}$. From morphological evaluation it was observed that ouabain inhibition of the $\mathrm{Na}^{+}, \mathrm{K}^{+}$-ATPase enzyme resulted in a dose-dependent inhibition of apoptosis associated cell shrinkage, with $20-25 \%$ of cells pre-treated with $3 \mu \mathrm{M}$ ouabain undergoing cytoplasmic condensation, in comparison to approximately $5 \%$ of cells pre-treated with $800 \mu \mathrm{M}$ undergoing cell shrinkage (Figure 4B). In contrast, control cultures (absence of ouabain) exhibit $60-80 \%$ of the cell population undergoing cytoplasmic condensation following induction of apoptosis. Similarly, staining of cytocentrifuge preparations demonstrated that while cytoplasmic condensation and apoptotic body formation was prevented by inhibition of the ouabain sensitive $\mathrm{Na}^{+} / \mathrm{K}^{+}$-ATPase, nuclear condensation occurred following UV irradiation (Figure $4 \mathrm{C}$ ). Cells with fragmented nuclei are clearly visible in the ouabain treated cultures, where progression to the subsequent phase of the apoptotic process is inhibited.

\section{Ouabain treatment does not inhibit DNA fragmentation}

While ultra structural alterations of the cytoplasm are relatively ill-defined, the nucleus undergoes a relatively characteristic transformation during apoptosis (Walker et al, 1995; Allen et al, 1993; White, 1996). Initially, chromatin condensation followed by nuclear fragmentation into fragments of 180200 base pairs in length has become a prominent indicator of apoptosis in HL-60 cells. Although ouabain treatment inhibited apoptosis associated cell shrinkage and apoptotic body formation, it appeared from morphological examination to have occurred independently of nuclear condensation (Figure 4C), suggesting that DNA fragmentation was still occurring. However, we cannot discern if the fragmentation seen is coming from all the cells or those that have shrunken in size. To verify that inhibition of the $\mathrm{Na}^{+} / \mathrm{K}^{+}$-ATPase was having no effect on DNA fragmentation, DNA was isolated from cells which had been treated with ouabain for cell volume studies and subsequently induced to undergo apoptosis (Figure 4D). A characteristic ladder of nucleosome-sized DNA fragments was observed in irradiated HL-60 cells. Similarly, cells pre-treated with ouabain and then induced to undergo apoptosis underwent significant DNA fragmentation, even though it prevented cell shrinkage and apoptotic body formation, both highly characteristic of apoptosis. No DNA fragmentation was observed in untreated HL-60 cells or in cells treated with ouabain alone. Therefore, ouabain inhibition of cell shrinkage occurs independently of apoptosis associated chromatin condensation and DNA fragmentation.

\section{Cell shrinkage is independent of changes in $\mathrm{Na}^{+} /$ $\mathrm{K}^{+}$-ATPase expression}

Because apoptosis is associated with a characteristic decrease in cell volume which can be prevented on inhibition of the $\mathrm{Na}^{+} / \mathrm{K}^{+}$-ATPase pump, it was speculated that this cell shrinkage may be regulated or accommodated through a change in the half-life or activity of the $\mathrm{Na}^{+} / \mathrm{K}^{+}$-ATPase enzyme. Firstly, studies were performed in HL-60 cells following the induction of apoptosis to determine $\mathrm{Na}^{+} / \mathrm{K}^{+}$ATPase $\alpha, \beta$-heterodimer protein levels, and to determine if any changes occurred at the protein level (Figure 5). The $\mathrm{Na}^{+} / \mathrm{K}^{+}$ATPase appeared as a heterodimer and no change in the protein levels were observed as cells were induced to undergo apoptosis over a $4 \mathrm{~h}$ period. Any changes in the protein levels would have been expected prior to or at the initial stage of cell shrinkage, 1-2 h post-induction of apoptosis. Therefore rapid ion efflux which would be associated with cell shrinkage is not accommodated through an alteration in the rate of synthesis of new $\mathrm{Na}^{+} / \mathrm{K}^{+}$-ATPase molecules.

\section{Intracellular free sodium concentrations decrease in apoptotic cells}

Because a reduced cell volume is associated with the extrusion of water from the apoptotic cell, which is possibly 
preceeded by the loss of specific ion(s), and due to the observed prevention of apoptotic cells shrinkage following inhibition of the $\mathrm{Na}^{+} / \mathrm{K}^{+}$-ATPase, we decided to determine if there were any alterations in the distribution of $\mathrm{Na}^{+} / \mathrm{K}^{+}$ions during the apoptotic process leading to and during cell shrinkage.

A number of workers have reported that prolonged exposure to ouabain and other cardiac glycosides, results in an increase in intracellular free sodium concentrations
$\left(\left[\mathrm{Na}^{+}\right]_{\mathrm{i}}\right)$, and cell swelling. Figure $6 \mathrm{~A}$ is a histogram of the fluorescence distribution of $\left[\mathrm{Na}^{+}\right]_{i}$ in $\mathrm{HL}-60$ cells, which were exposed to $100 \mu \mathrm{M}$ ouabain for varying time periods. Cultures supplemented with ouabain for $2 \mathrm{~h}$ showed no increase in the average Sodium Green fluorescence over non-treated cells. Between $4-6 \mathrm{~h}$ post ouabain treatment there was a significant increase in Sodium Green fluorescence indicating a sustained rise in cytosolic sodium (Figure $6 \mathrm{~A}$ ). These findings are in agreement with

A

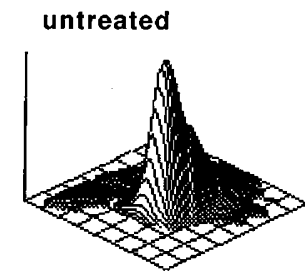

ouabain
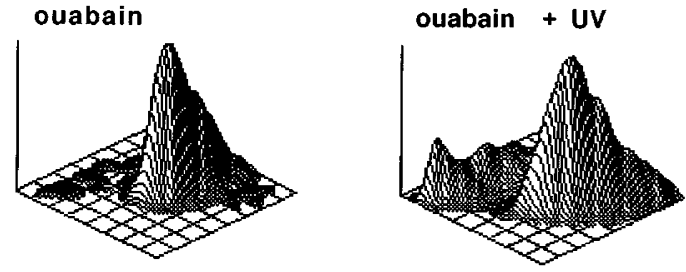

B

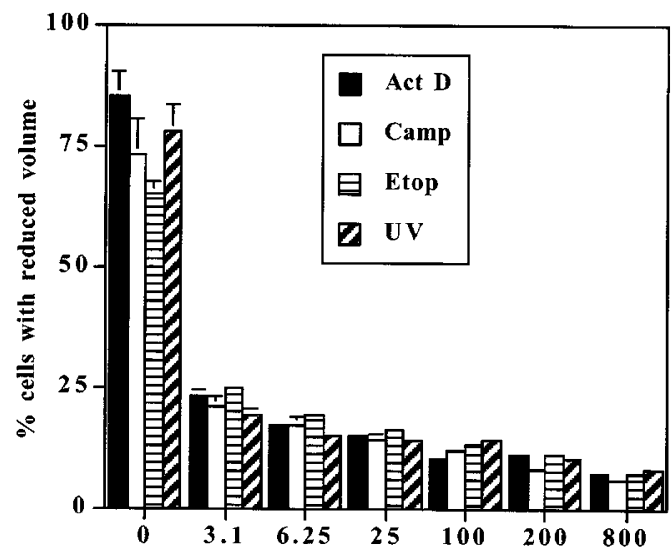

C
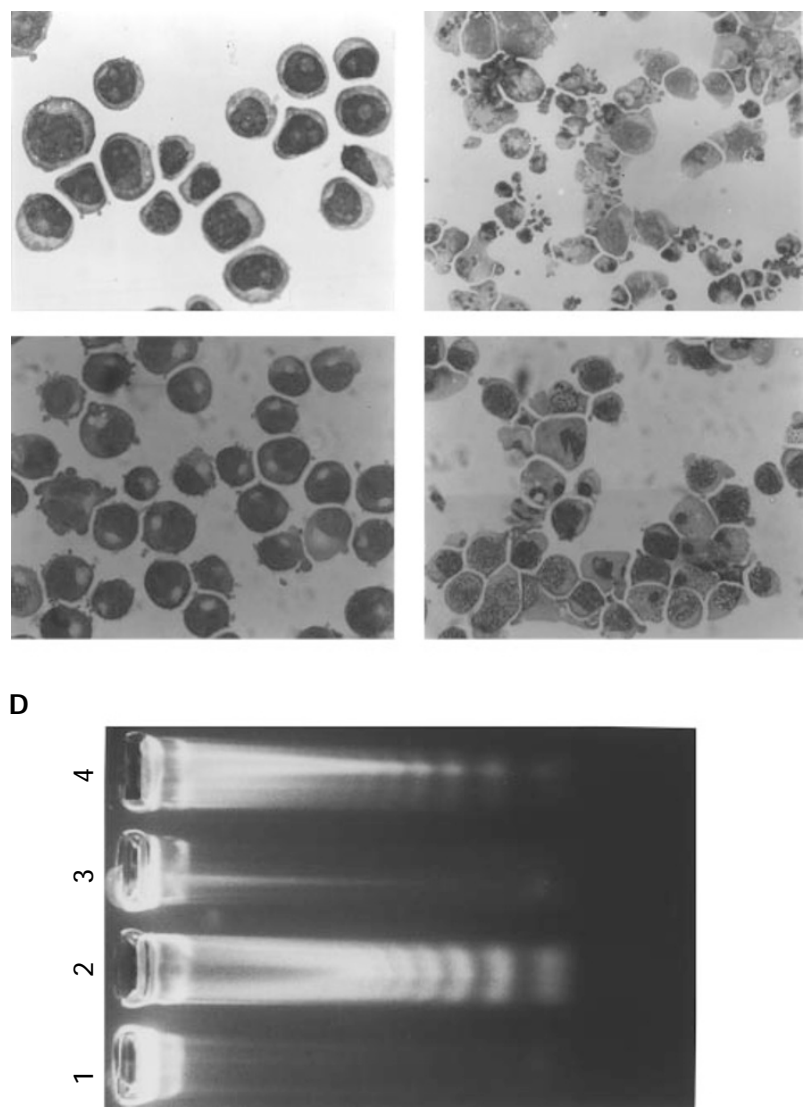

Ouabain $(\mu \mathrm{M})$

Figure 4 Inhibition of the ouabain-sensitive $\mathrm{Na}^{+}, \mathrm{K}^{+}$-ATPase prevents apoptotic cell shrinkage and subsequent apoptotic body formation. (A) A 3-dimensional plot of untreated cells, UV-irradiated, ouabain $(100 \mu \mathrm{M})$ treated and ouabain $(100 \mu \mathrm{M})$ treated UV-irradiated cells. See Materials and Methods section for incubation details. In each case forward scatter (cell size) is plotted against side scatter. Note the appearance of an apoptotic cell peak (arrow), and larger apoptotic body subpopulation typified by a further reduction in cell size and granularity in irradiated cells. The occurrence of these populations in ouabain treated irradiated cultures are inhibited. (B) HL-60 cells were treated with varying concentrations of ouabain $(3 \mu \mathrm{M}-800 \mu \mathrm{M})$ and induced to undergo apoptosis when UV-irradiated or treated with $5 \mu \mathrm{g} / \mathrm{ml}$ actinomycin-D, $5 \mu \mathrm{g} / \mathrm{ml}$ camptothecin or $25 \mu \mathrm{g} / \mathrm{ml}$ etoposide. Cell shrinkage was determined by flow cytometric analysis. Results are representative of typical values obtained and are expressed as the mean cell number \pm S.E.M. (C) The morphologies of exponentially growing (A), UV-irradiated (B), ouabain $(100 \mu \mathrm{M})$ treated $(\mathbf{C})$ and ouabain $(100 \mu \mathrm{M})$ treated irradiated HL-60 cells (D). Typical apoptotic features displayed by irradiated cells include cell shrinkage, chromatin condensation and apoptotic body formation, while irradiated cells treated with ouabain demonstrate chromatin condensation with no cell shrinkage or apoptotic body formation. Magnification $\times 400$. (D) DNA was extracted from untreated cells (Lane 1), UV-irradiated cells (Lane 2), cells treated with $100 \mu$ M ouabain for $3 \mathrm{~h}$ (Lane 3 ) and ouabain treated UV-irradiated cells (Lane 4). In each situation DNA from $5 \times 10^{5}$ cells was electrophoresed through a $1.5 \%$ agarose gel and stained with ethidium bromide 
others (Trump et al, 1981), and demonstrate that within the $2 \mathrm{~h}$ time period of these experiments the effect of ouabain on $\left[\mathrm{Na}^{+}\right]_{\mathrm{i}}$ was insignificant and would not interfere with subsequent $\left[\mathrm{Na}^{+}\right]_{\mathrm{i}}$ determinations in apoptotic or ouabain treated apoptotic cells.

It has been shown that by exploiting the light scattering properties of a cell population by flow cytometry one can detect the emergence of a population characterised by a decrease in forward light scatter, lower than that of normal viable cells, which correlates with the occurrence of apoptotic cells with a shrunken morphology (McGahon et al, 1995; Gorman et al, 1996; Cotter et al, 1992). In the present experiments, a prominent population with reduced FSC developed in UV-irradiated cultures (Figure 6B, R2). This cell size difference between the viable and apoptotic populations allows us to discriminate between other characteristics of the cell which change during the apoptotic death process i.e. alterations in DNA content as determined by PI binding, or as in this study, alterations in intracellular sodium associated fluorescence.

Figure $6 \mathrm{C}$ represents a histogram of the fluorescence distribution of $\left[\mathrm{Na}^{+}\right]_{\mathrm{i}}$ in HL-60 cells $2 \mathrm{~h}$ post UV-irradiation. The fluorescence associated with $\mathrm{Na}^{+}$bound sodium green in irradiated cells shows the emergence of a population with reduced fluorescence, lower than that of viable cells (Figure 6C). By flow cytometric analysis of the fluorescence associated with cells gated in Figure $6 \mathrm{~B}$, it was concluded that this population with reduced sodium green binding is representative of the apoptotic cells with reduced FSC (Figure 6C). Intracellular free sodium concentrations also decreased in HL-60 cells when actinomycin-D, was used as the inducing agent, indicating that decreased intracellular sodium concentrations seen in Figure $6 \mathrm{C}$ were not peculiar to UV-irradiation (data not shown). From progressional studies involving both flow cytometric analysis and morphological evaluations we are able to conclude that UV-irradiation of HL-60 cell cultures caused a decrease in intracellular free sodium concentrations, occurring after visualisation of chromatin condensation and prior to apoptotic body formation.

122304556

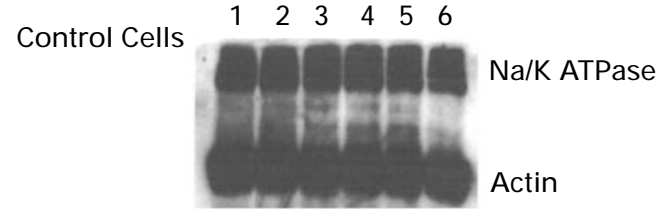

Apoptotic Cells

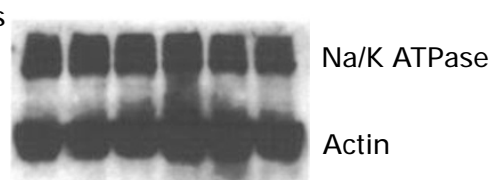

Figure $5 \mathrm{Na}^{+} / \mathrm{K}^{+}$-ATPase protein levels in irradiated HL-60 cells. HL-60 cells were either left untreated (lane 1) or UV-irradiated for 10 min and cultured for $4 \mathrm{~h}$. Cell lysates were prepared from the treated samples after $30 \mathrm{~min}$ (lane 2) and every hour post-irradiation (lanes $3-6$ ), protein levels were examined by immunoblot analysis using anti- $\mathrm{Na}^{+} / \mathrm{K}^{+}$-ATPase and HRP-conjugated antimouse $\operatorname{lgM}$ as described in Materials and Methods. The positions of $\mathrm{Na}^{+} / \mathrm{K}^{+}$ATPase heterodimer protein and actin are marked

\section{Ouabain inhibits apoptosis associated decrease in $\left[\mathrm{Na}^{+}\right]_{\mathrm{i}}$}

To further characterise the relationship between sodium efflux and apoptotic cell shrinkage, $\left[\mathrm{Na}^{+}\right]_{\mathrm{i}}$ was determined in apoptotic cultures which were supplemented with ouabain, to determine if inhibition of the $\mathrm{Na}^{+} / \mathrm{K}^{+}$-ATPase would prevent the observed sodium efflux. Figure $6 \mathrm{D}$ is a histogram of the fluorescence distribution of $\left[\mathrm{Na}^{+}\right]_{i}$ in irradiated cells with or without ouabain treatment $(100 \mu \mathrm{M})$. Apoptotic cultures supplemented with ouabain for $2 \mathrm{~h}$ prevented the appearance of the population with reduced intracellular sodium.

A

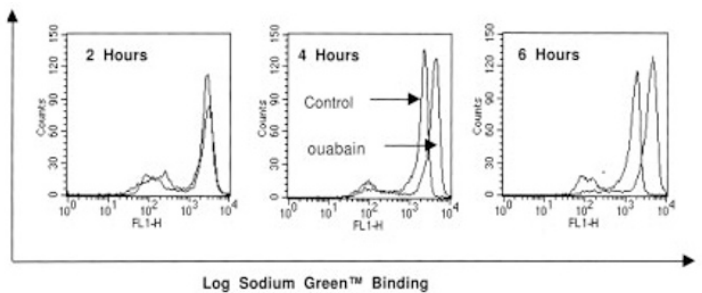

B
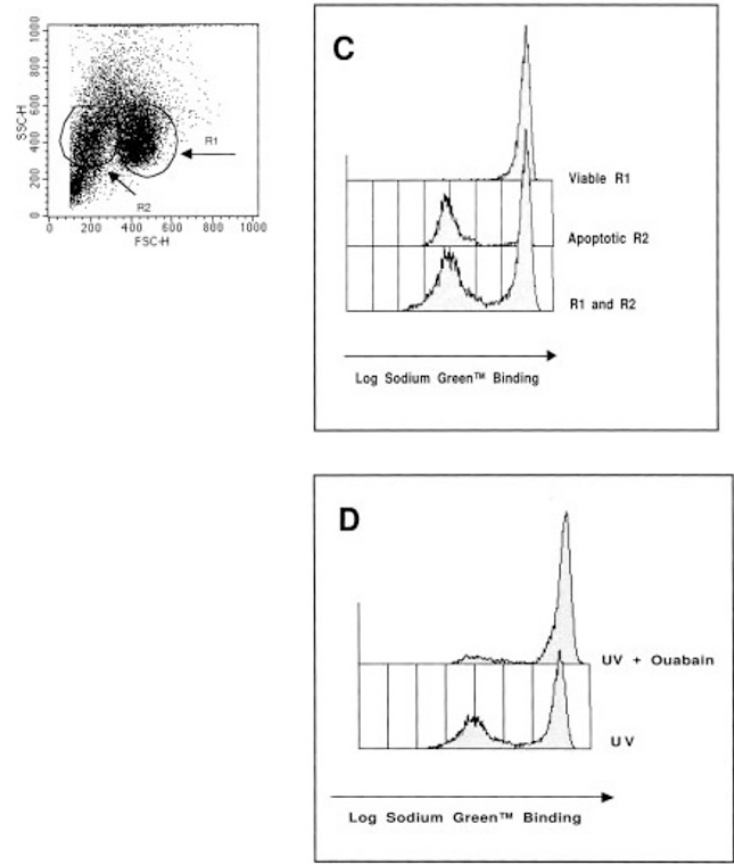

Figure 6 Apoptosis associated cell shrinkage involves a decrease in intracellular free sodium concentrations. (A) Exponentially growing HL-60 cultures were cultured in medium alone or in medium supplemented with $100 \mu \mathrm{M}$ ouabain for varying time periods. At the indicated time points, cells were loaded with the fluorescent labelled $\mathrm{Na}^{+}$binding cell-permeant tetraacetate salt of Sodium Green ${ }^{\text {TM }}$ Fluorescence, indicative of $\mathrm{Na}^{+}$ concentrations, was determined on a FACscan flow cytometer as described in Materials and Methods. (B) Light scatter properties on UV irradiated cells showing distinct and separate populations of viable cells, apoptotic cells and apoptotic bodies. (C) Histogram of the fluorescence distribution of intracellular free sodium in UV-irradiated cells. Gates indicated in (B) provide boundaries for analysis of the representative fluorescence of the separate viable and apoptotic cells. (D) Irradiated cells treated or untreated with ouabain were loaded with Sodium Green ${ }^{\mathrm{TM}}$ and intracellular free sodium concentrations were determined on a FACscan flow cytometer as described in Materials and Methods 
From earlier experiments it was concluded that ouabain also inhibited the cell shrinkage associated with apoptosis (Figure 4), therefore, by corollary, sodium efflux from apoptotic cells may play an important role in apoptosis associated cell shrinkage and apoptotic body formation, both of which are preventable by inhibition of the $\mathrm{Na}^{+} / \mathrm{K}^{+}$-ATPase.

\section{Inhibition of the $\mathrm{Ca}^{2+}$-dependent potassium channel prevents apoptosis associated cell shrinkage}

Since cell volume changes are a prominent feature in apoptotic HL-60 cells and following the demonstration that sodium efflux is associated with cell shrinkage in these cells, this study was extended to determine if a similar efflux of potassium ions was associated with apoptotic cell shrinkage in HL-60 cells. Exponentially growing HL-60 cell cultures were treated with increasing concentration of Tetra-Pentyl Ammonium (TPA), a specific inhibitor of the calcium-dependent potassium channel, for a period of $2 \mathrm{~h}$ following UVirradiation. Cells were analysed morphologically and by flow cytometry to investigate whether TPA could prevent apoptotic cell shrinkage. Figure 7A shows the 3-dimensional profiles of the forward and side scatter determined for control HL-60 cells, UV-irradiated cells, and finally cells treated with varying concentrations of TPA following UV-irradiation. UV-irradiated

A

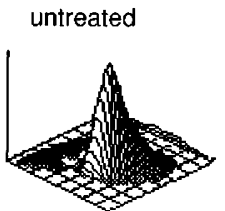

UV-irradiated

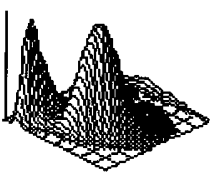

$50 \mu \mathrm{M}$ TPA

$10 \mu \mathrm{M}$ TPA

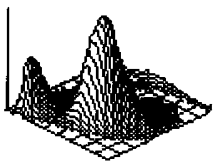

$0.1 \mu M$ TPA

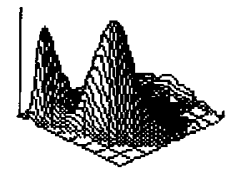

$100 \mu \mathrm{M}$ TPA

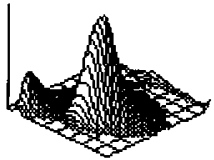

B

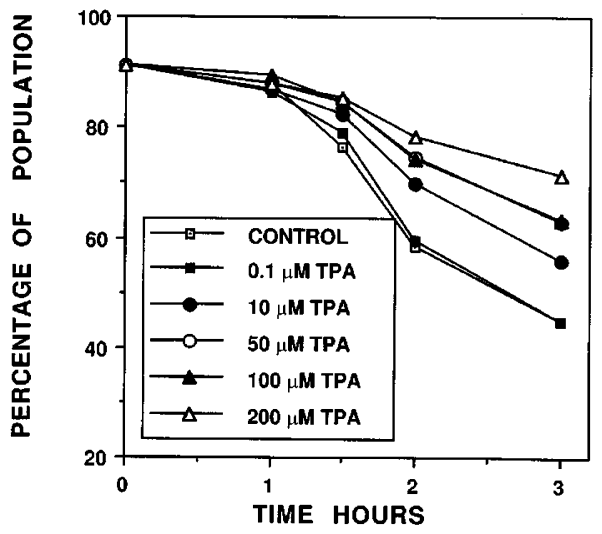

C
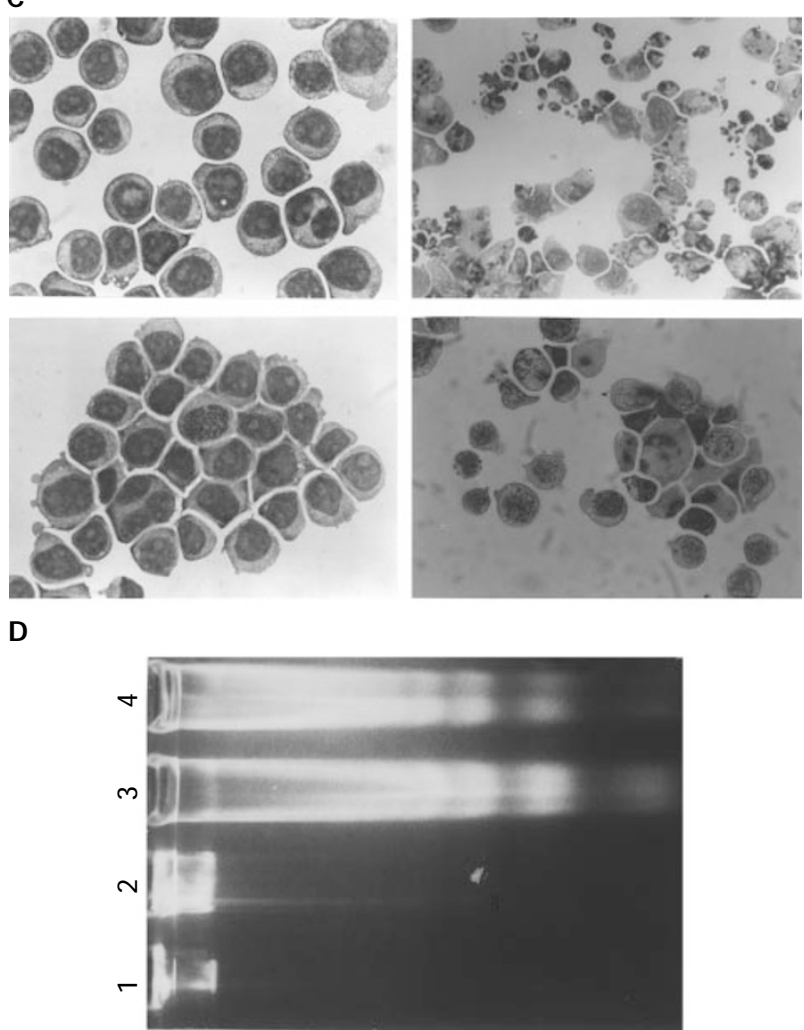

Figure 7 Inhibition of the calcium-dependent potassium channels prevents apoptosis related cell shrinkage. (A) A 3-dimensional plot of untreated cells, UVirradiated cells and cells exposed to the indicated concentrations of TPA following UV-irradiation. In each case forward light scatter (cell size) is plotted against side light scatter. Note the appearance of an apoptotic cell peak in irradiated cells. The occurrence of this population in TPA treated irradiated cultures is prevented in a dose-dependent manner. Results are representative of a typical experiment. (B) HL-60 cells were exposed to the indicated concentrations of TPA following UVirradiation for $10 \mathrm{~min}$. Cell shrinkage was determined by flow cytometric analysis and results are representative of typical values obtained in four separate experiments. (C) The morphologies of exponentially growing (A), UV-irradiated (B), TPA (100 $\mu \mathrm{M})$ treated (C) and TPA (100 $\mu$ M) treated UV-irradiated cells (D). Typical apoptotic features are displayed by irradiated cells, while irradiated cells treated with TPA demonstrate chromatin condensation with reduced cell shrinkage and apoptotic body formation. Magnification $\times 400$. (D) Detection of internucleosomal DNA fragmentation in TPA treated cells. DNA was extracted from untreated cells (Lane 1), cells treated with $100 \mu \mathrm{M}$ TPA for $3 \mathrm{~h}$ (Lane 2), UV-irradiated cells (Lane 3 ), and TPA treated UV-irradiated cells (Lane 4). DNA from $5 \times 10^{5}$ cells was electrophoresed through a $1.5 \%$ agarose gel and stained with ethidium bromide 
cultures demonstrated normal cell shrinkage associated with apoptosis, however, treatment of irradiated cultures with TPA prevented this shrinkage in a dose dependent manner (Figure 7A).

Statistical analysis of this data confirmed that inhibition of the calcium-dependent potassium channel prevented apoptotic cell shrinkage in a dose dependent manner (Figure 7B). From flow cytometric analysis $44 \%$ of UVirradiated cells maintained a relatively normal cell volume $3 \mathrm{~h}$ post-UV-irradiation, while $71 \%$ of TPA $(200 \mu \mathrm{M})$ treated irradiated cells maintained a normal volume when compared to non-irradiated cells. Cultures treated with increasing concentrations of TPA alone did not alter their respective volumes (data not shown).

Morphological evaluation of the characteristics of TPA treated and TPA treated irradiated cells revealed that despite the inhibition of cytoplasmic condensation and fragmentation, TPA did not interefere with the progression of chromatin condensation and nuclear fragmentation in apoptotic cells (Figure 7C). These morphological observations were confirmed when DNA from TPA and TPA treated irradiated cells was separated by DNA gel electrophoresis (Figure 7D). Cultures treated with TPA alone were morphologically indistinguishable from control cultures and did not fragment their DNA, while irradiated cells treated with TPA demonstrated chromatin condensation and extensive internucleosomal DNA fragmentation following DNA electrophoresis. It is noteworthy to mention that following prolonged exposure to TPA (over $3 \mathrm{~h}$ ) the higher concentrations of TPA used in this study induced extensive apoptosis, therefore all experiments were conducted within $2-3 \mathrm{~h}$.

\section{Apoptosis related cell shrinkage in HL-60 cells is associated with a decrease in intracellular free potassium concentrations}

Because inhibition of $\mathrm{K}^{+}$efflux by inhibiting the calcium dependent channel prevented apoptotic cell shrinkage, $\mathrm{K}^{+}$ concentrations were determined in control and apoptotic cells to investigate if apoptosis was associated with an efflux of potassium ions. As measured by spectrofluorometry, with the $\mathrm{K}^{+}$sensitive probe $\mathrm{PBFI}$, the ratio of luminescence obtained by exciting the cells at wavelengths of 340 and $380 \mathrm{~nm}$ while measuring at a constant emission of $510 \mathrm{~nm}$ is indicative of $\left[\mathrm{K}^{+}\right]_{i}$ due to the observation that the fluorescence of the dye was particularly sensitive to $\left[\mathrm{K}^{+}\right]_{\mathrm{i}}$ when excited at $340 \mathrm{~nm}$, yet was relatively unaffected when excited at $380 \mathrm{~nm}$ (data not shown). In control HL-60 cells an average value for intracellular free potassium levels of $177 \mathrm{nM}$ was obtained using this protocol (Materials and Methods). However, it must be borne in mind that sodium levels, even though they are considerably lower than potassium levels in the cell and PBFI has a higher affinity for potassium, can interfere with the PBFI detection and these data must be viewed as qualitative rather than quantitative. Following the induction of apoptosis by UV-irradiation the concentration of intracellular free sodium decreased from an average $117 \mathrm{mM}$ in control cells to a value of approximately $65 \mathrm{mM}$ in apoptotic cultures (Figure 8).
A

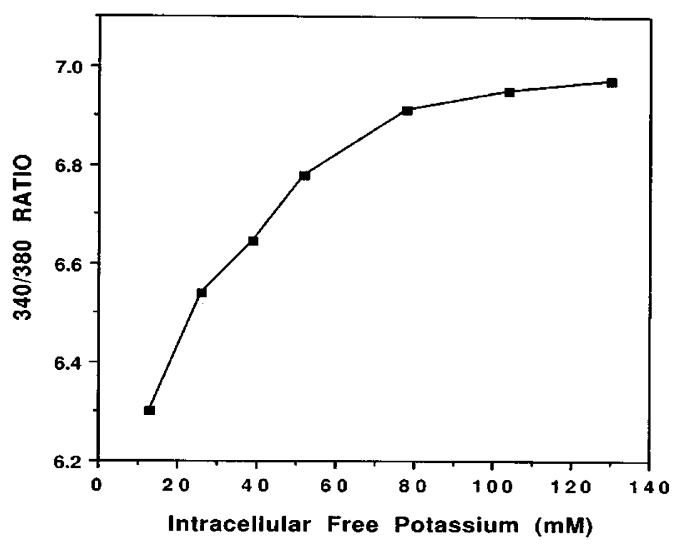

B
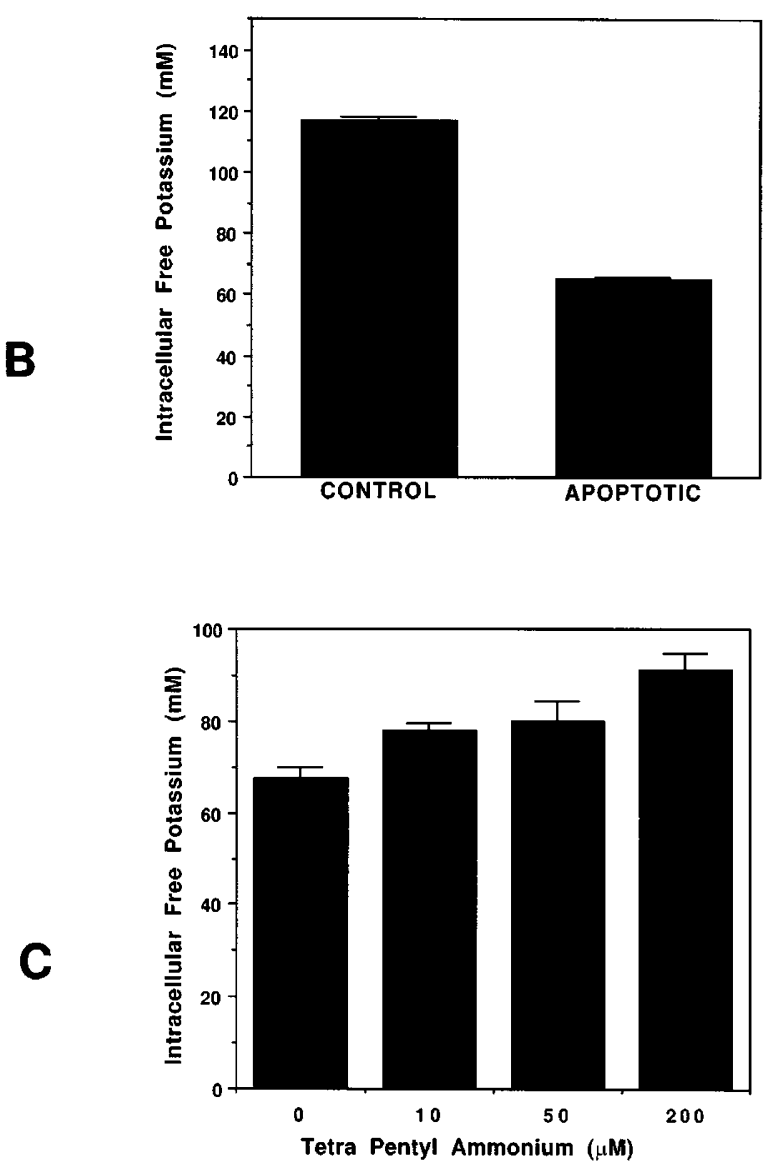

Figure 8 Apoptosis associated cell shrinkage involves a decrease in intracellular potassium. (A) In situ calibration curve for PBFI, see Materials and Methods for complete procedure and details. (B) HL-60 cell cultures were either untreated or induced to undergo apoptosis following UV-irradiation. Two hours post-irradiation the concentration of intracellular free potassium was determined by spectrofluoremetry using the $\mathrm{K}^{+}$sensitive probe PBFI, as described in Materials and Methods. Results are expressed as mean $\left[\mathrm{K}^{+}\right]_{\mathrm{i}} \pm$ S.E.M. (C) HL-60 cell cultures were supplemented with the indicated concentrations of TPA and induced to undergo apoptosis by UV-irradiation. Intracellular free potassium concentrations were determined by spectrofluoremetry using the $\mathrm{K}^{+}$sensitive probe PBFI, as described in Materials and Methods. Results are expressed as mean $\left[\mathrm{K}^{+}\right]_{i} \pm$ S.E.M. 


\section{Inhibition of $\mathrm{K}^{+}$efflux by TPA prevents apoptosis associated cell shrinkage}

To further investigate the involvement of a potassium ion efflux during apoptotic HL-60 cells shrinkage, $\left[\mathrm{K}^{+}\right]_{i}$ was determined in UV-irradiated cultures which had been supplemented with the potassium channel inhibitor TPA, to determine if TPA could inhibit this $\mathrm{K}^{+}$efflux. As determined by spectrofluorometry, Figure $8 \mathrm{C}$ is a graphical representation of values obtained for $\left[\mathrm{K}^{+}\right]_{i}$ in UV-irradiated cultures which were supplemented with increasing amounts of TPA. It is evident that TPA inhibits this apoptosis associated $\mathrm{K}^{+}$efflux in a dosedependent manner. Cultures supplemented with $200 \mu \mathrm{M}$ TPA demonstrated an average $\left[\mathrm{K}^{+}\right]_{\mathrm{i}}$ of $90 \mathrm{mM}$ while cultures supplemented with $50 \mu \mathrm{M}$ and $10 \mu \mathrm{M}$ revealed concentrations of $80 \mathrm{mM}$ and $78 \mathrm{mM}$ respectively (Figure $8 \mathrm{C}$ ). These values closely reflect the dose dependent inhibition of cell shrinkage by TPA described earlier (Figure 7), implying that an efflux of potassium ions during HL-60 apoptosis may be essential for the occurrence of cell shrinkage.

\section{Discussion}

Among the classical features of apoptosis, cell shrinkage is of considerable physiological importance, occurring in most cell types in response to a variety of endogenous or exogenous stimuli. The significance of controlled apoptotic cell shrinkage is emphasised by events which ensue during uncontrolled necrotic cell death, which is associated with a general increase in permeability of the PM, either through structural changes affecting membrane pores and channels or by inhibition of membrane ionic pumps (Bowen and Bowen, 1990). The impairment of the cell membrane, cytoskeleton and ion regulation in the context of necrotic cell death is associated with an abandonment of PM integrity and ion gradients leading to a loss of $\mathrm{K}^{+}$and an influx of $\mathrm{Ca}^{2+}$ and $\mathrm{Na}^{+}$ which in turn initiate an uptake of water causing irreversible damage, cell swelling and eventual cell lysis (Trump et al, 1981). In contrast, apoptotic cell death is characterised by an isolation of the cell from its surroundings (Dransfield et al, 1994) and the initiation of a well regulated process including cell shrinkage and maintenance of PM integrity (Morris et al, 1984; Cohen et al, 1992). During apoptosis cells have been reported to shrink to between $70 \%$ (Thomas and Bell, 1981) and $40 \%$ (Beauvais et al, 1995) of the cells original volume, the PM becomes convoluted losing specialised structures such as microvilli and desmosomes, and in most instances the cell fragments into apoptotic bodies (Kerr et al, 1972). From these descriptions and the complexity of associated membrane and volume alterations it is obvious that apoptotic cell shrinkage involves strict regulation.

In the present study, by directly measuring lipid redistribution following UV-irradiation, substantial evidence is provided to suggest that the decrease in cell volume associated with apoptosis is not mediated through and increased PM permeability to osmotically active particles (Figures 2 and 3 ). This conclusion is supported by studies suggesting no direct association between membrane fluidity and permeability to $\mathrm{Na}^{+}$or $\mathrm{Cl}^{-}$ions (Lande et al, 1995). PS externalisation, as reported previously, is one of the earliest indicators of apoptotic cell death (Martin et al, 1995), and as reported here is associated with a decrease in lipid polar-head group packing. Importantly, both features occur independently of alterations in PM permeability, a feature which is more characteristic of late stage apoptosis. In addition, on analysis of cell size distribution (excluding the apoptotic body population) only two populations with sizes representative of viable and apoptotic cells were detected. In the experiment described (Figure 1), further analysis revealed that following the induction of apoptosis, cell shrinkage once initiated is a very rapid process, which is evident from the detection of no intermediate sized cells between normal and shrunken populations. This is the hallmark of a rapid process, further emphasising the need for strict regulatory mechanisms.

Because apoptosis is associated with a dramatic reduction in cell volume and apoptotic body formation, the cytoskeleton and lipid bi-layer must also experience structural alterations and re-organisation. The plasma membrane of healthy cells exhibits an asymmetric distribution of its major phospholipids, however, following the induction of apoptosis in HL-60 cells, PS is translocated to the external leaflet, (Figure 2A, Martin et al, 1995) where it serves as a recognition signal for phagocytosis by certain populations of macrophages (Fadok et al, 1992a,b, 1993). PS derived from natural sources often contains a high level of unsaturated fatty acid side chains, and its translocation to the external leaflet during apoptosis might therefore loosen the packing of the bi-layer. Indeed following UVirradiation of HL-60 cell cultures, a time dependent decrease in the packing of lipid bi-layers was detected when stained with MC540, which preferentially stains loosely packed or disordered membranes (Figure 2B). This observation suggests that apoptosis of HL-60 cells is associated with either an increased membrane fluidity or a loosening of lipid packing near the polar head groups. This proposal is consistent with observations made by others where MC540 preferentially bound to fluid-phase vesicles in comparison to their gel-phase counterparts (Williamson et al, 1983).

This decrease in lipid packing of apoptotic HL-60 cells paralleled the externalisation of PS and occurred several hours before any alterations in membrane permeability, as membranes remained impermeant to vital dye and continue to exclude PI (Figure 2C). The fact that MC540 binds more strongly to apoptotic cells and occurs coincident with PS translocation to the external leaflet, implicates PS externalisation (which would decrease the packing of the hydrophobic head group) rather than altered membrane permeability as the primary determinant of increased MC540 bilayer affinity. This conclusion is supported by the observation that when platelets are activated (Beavers et al, 1982) or erythrocytes are loaded with $\mathrm{Ca}^{2+}$ (Rosing et al, 1985), PS is externalised and is paralleled by an increased binding of MC540 (Williamson et al, 1983). Similarly, the surface of apoptotic T-lymphocytes in vivo and in vitro demonstrate an increased binding of MC540 (Schlegel et al, 1993), which also externalise PS during apoptosis (Fadok et al, 1992a,b, 1993). Thus the reported increase in membrane fluidity/loosening of polar head 
groups, associated with apoptosis in HL-60 cells is not likely to alter membrane permeability to ionic regulators of cell volume but represents a secondary characteristic due to PS externalisation during apoptosis.

The mechanism leading to cell shrinkage during apoptosis remains obscure, however it has been suggested to involve the fusion of internal fluid filled membrane bound vesticles with the plasma membrane (Morris et al, 1984; Cohen et al, 1992). As stated earlier, under normal physiological conditions, it is believed that cell volume is largely dependent on cellular control of osmotically active particles such as $\mathrm{K}^{+}, \mathrm{Cl}^{-}$, and $\mathrm{Na}^{+}$. In line with this proposal, this study demonstrates that HL-60 cell apoptosis is mediated through a redistribution of intracellular ion content, particularly $\mathrm{K}^{+}$and $\mathrm{Na}^{+}$. Several studies have demonstrated that alterations in the activity of the $\mathrm{Na}^{+}, \mathrm{K}^{+}-$ ATPase pump are associated with adverse effects on intracellular sodium concentration gradients and cell volume. In the absence of pump activity, the transmembrane sodium gradient dissipates and the cell eventually swells due to the presence of non-diffusible intracellular macromolecules (Macknight, 1988) while $\left[\mathrm{Na}^{+}\right]_{i}$ decrease and cell volume decreases in response to elevated pump activity. As determined by flow cytometry, we demonstrate that following UV-irradiation, apoptosis associated cell shrinkage is accompanied by a parallel decrease in $\left[\mathrm{Na}^{+}\right]_{\mathrm{i}}$ (Figure 6). Progressional studies involving morphological and flow cytometric evaluation, and DNA gel electrophoresis reveal that the observed decrease in $\left[\mathrm{Na}^{+}\right]_{i}$ occurs after visualisation of chromatin condensation and DNA fragmentation, and prior to apoptotic body formation. When apoptotic cultures were supplemented with ouabain $(100 \mu \mathrm{M})$, its effect on $\mathrm{Na}^{+}$efflux was dramatic resulting in near complete inhibition of apoptosis associated $\mathrm{Na}^{+}$ efflux (Figure 6). Indicating that essentially all of the $\mathrm{Na}^{+}$ efflux during apoptosis can be ascribed to active pumping via the $\mathrm{Na}^{+}, \mathrm{K}^{+}$-ATPase pump. This conclusion is supported by observations from other studies, whereby $\mathrm{Na}^{+}$efflux from human neutrophils was $95 \%$ inhibited by the presence of $50 \mu \mathrm{M}$ ouabain (Simchowitz et al, 1982).

Signals leading to the activation or inhibition of the $\mathrm{Na}^{+}$, $\mathrm{K}^{+}$-ATPase pump are not clear, and to date at least five different mechanisms have been proposed, any of which may be involved in modulating the activity of the $\mathrm{Na}^{+}, \mathrm{K}^{+}$ATPase pump during apoptosis. These include the phosphorylation status or the catalytic $\alpha$ subunit of $\mathrm{Na}^{+}$, $\mathrm{K}^{+}$-ATPase (Bertorello et al, 1991); alterations in $\left[\mathrm{Na}^{+}\right]_{i}$ (Whalley et al, 1993); changes in the concentrations of intracellular macromolecules (reviewed in Hallbrucker et al, 1991); membrane deformations associated with cell volume changes; and finally the lipid composition of a cell membrane where it has been proposed that alterations in lipid distribution and lipid packing can affect the transport functions of the pump (Whalley et al, 1993).

Further evidence exists which supports a role for the $\mathrm{Na}^{+}, \mathrm{K}^{+}$-ATPase pump in apoptosis related cell shrinkage and includes the dependence of the apoptotic process on the presence of functional mitochrondria. During necrosis mitochrondrial calcium overload leads to depletion of ATP, which initiates a cascade of events culminating in un- controlled necrotic cell death (Bowen and Bowen, 1990). In relation to cell volume, reduction in ATP levels causes a rapid inhibition of the $\mathrm{Ca}^{2+}$-ATPase pumps in the $\mathrm{PM}$, endoplasmic reticulum and inner mitochondrial membranes, leading to increased cytosolic calcium levels. This dissipation of ionic gradients is further effected by inhibition of the $\mathrm{Na}^{+}, \mathrm{K}^{+}$-ATPase pumps resulting in increased intracellular levels of $\mathrm{Na}^{+}$, culminating in further increased calcium levels and cell swelling. It is well documented that apoptosis is an energy (ATP) dependent process with functional mitochondria persisting until later stages in apoptotic cell death, therefore energy is still available to potentially drive $\mathrm{Na}^{+}, \mathrm{K}^{+}$-ATPase pumps and assist in cell shrinkage (Bowen and Bowen, 1990).

In addition to being the most abundant intracellular ion, $\mathrm{K}^{+}$is a critical component of the volume regulatory response (Hoffmann and Simonsen, 1989), and leakage of $\mathrm{K}^{+}$could be a simple way to accommodate a rapid decrease in cell volume. Such a mechanism has been suggested in hepatic cells where cell shrinkage may be mediated through $\mathrm{K}^{+}$channels (Hallbrucker et al, 1991). In this study following induction of apoptosis in HL-60 cells, $\left[\mathrm{K}^{+}\right]_{\mathrm{i}}$ decreased by approximately $50 \%$ in comparison to control cultures. Furthermore, Tetrapentyl ammonium, a specific $\mathrm{Ca}^{2+}$-dependent $\mathrm{K}^{+}$channel inhibitor, inhibited cell shrinkage and apoptotic body formation during apoptosis in a dose dependent manner. These observations are in line with recent studies where Beauvais et al (1995) have demonstrated that eosinophil shrinkage during apoptosis can be reduced by inhibitors of $\mathrm{K}^{+}$channels, while Barbiero et al (1995) have demonstrated reduced intracellular concentration of $\mathrm{K}^{+}$in apoptotic murine $\mathrm{L}$ cells.

The reduction in cellular solute content during RVD has been attributed to the outward movement of $\mathrm{K}^{+}$and $\mathrm{Cl}^{-}$ ions mediated by a number of transport pathways, including independent $\mathrm{K}^{+}$and $\mathrm{Cl}^{-}$conductance (Cahalan and Lewis, 1988; Hoffmann, 1985). The precise mechanism of $\mathrm{K}^{+}$ efflux during RVD is currently under debate with two particular fields of thought. Initially, and perhaps the more attractive proposal, based on the current study and our understanding of the apoptotic process, suggests the involvement of an active $\mathrm{K}^{+}$efflux via a $\mathrm{Ca}^{2+}$-dependent $\mathrm{K}^{+}$channel. A central role during all phases of the apoptotic process appear to be mediated by a progressive influx of calcium ions resulting in a sustained increase in intracellular free calcium levels. Potential sites for the action of calcium in apoptotic cells are numerous (Nicotera et al, 1994a,b; Arends and Wyllie, 1991) and may include the activation of $\mathrm{Ca}^{2+}$-dependent $\mathrm{K}^{+}$channels which mediates apoptotic cell shrinkage. Support for this proposal comes from the inhibitory effects of quinine and cetiedil (inhibitors of $\mathrm{Ca}^{2+}$-activated $\mathrm{K}^{+}$permeability) on RVD, suggesting that $\mathrm{Ca}^{2+}$ might play a role in the activation or regulation of increased $\mathrm{K}^{+}$permeability as the cell returns to its physiological volume. In addition depletion of intracellular $\mathrm{Ca}^{2+}$ blocked RVD by inhibiting the increase in volume activated $\mathrm{K}^{+}$permeability (Grinstein et al, 1984). In HL-60 cells, apoptosis is associated with an increase in intracellular $\mathrm{Ca}^{2+}$ levels (Martin and Green, 1995; Nicotera et al, 1994a,b) and is diminished or delayed 
under conditions of low extracellular calcium, implying that $\mathrm{Ca}^{2+}$ influx is a requirement for apoptosis in this system. Together, these studies lead to the hypothesis that during the apoptotic process intracellular levels of $\mathrm{Ca}^{2+}$ are elevated which in turn activates a $\mathrm{Ca}^{2+}$-dependent $\mathrm{K}^{+}$ channel, through which apoptosis associated $\mathrm{K}^{+}$efflux is mediated, culminating in cell shrinkage.

The second mechanism proposed by Cahalan and Lewis (1988) suggests that the primary event in RVD is $\mathrm{Cl}^{-}$ channel activation which causes depolarisation of the plasma membrane potential and subsequently activates voltage dependent $\mathrm{K}^{+}$channels. Evidence which suggests the use of alternative $\mathrm{K}^{+}$transport pathways, other than the $\mathrm{Ca}^{2+}$-dependent $\mathrm{K}^{+}$channels, during apoptotic cell shrinkage, is derived from the observation that TPA delayed rather than inhibited cell shrinkage. Continuous assessment of cell volume changes in TPA treated irradiated cells revealed a slight yet appreciable time-dependent increase in the number of cells with reduced cell volumes (data not shown). However, this study suggests that the $\mathrm{Ca}^{2+}$ dependent $\mathrm{K}^{+}$channel is main transport mechanism for $\mathrm{K}^{+}$efflux during apoptosis.

The ion transport systems involved in volume regulation and in the maintenance of cell volume are often quiescent or operating at a low level in the resting cell, but are activated by changes in cell volume or by various external stimuli. From comparative analysis it is emerging that RVD and apoptosis have several potentially common signaling and functional characteristics which mediate cell shrinkage in both systems. The mechanisms of activation of RVD are poorly understood, but recently several factors have been assigned a regulatory function, including calcium, calmodulin and cAMP (Hoffmann and Simonsen, 1989). Similar to apoptosis, others have recently demonstrated that an increase in cytosolic calcium is a prerequisite of RVD (Hazama and Okada, 1988). Subsequently, a modulation of $\mathrm{Ca}^{2+}$ sensitive transport pathways have been suggested to participate in RVD in some cell systems. Separate conductive $\mathrm{K}^{+}$and $\mathrm{Cl}^{-}$transport pathways mediate an efflux of $\mathrm{K}^{+}$and $\mathrm{Cl}^{-}$during RVD (Hoffmann and Simonsen, 1989), and the identification of $\mathrm{Ca}^{2+}$-dependent $\mathrm{K}^{+}$channels (Schwartz and Passow, 1983) and $\mathrm{Cl}^{-}$-channels (Frizzell et al, 1986) supports the above proposal. The potential involvement of a $\mathrm{Ca}^{2+}$-dependent $\mathrm{K}^{+}$channel in apoptotic cell shrinkage is easily imagined when one considers the diversity of cellular activities initiated and regulated by $\mathrm{Ca}^{2+}$ during $\mathrm{HL}-60$ apoptosis (reviewed in Nicotera et al, 1994a,b). Apoptosis of HL-60 cells is paralleled by a considerable increase in intracellular $\mathrm{Ca}^{2+}$ levels, which is proposed to activate pivotal steps in the apoptotic process including proteases (Zhu et al, 1995), nucleases (Walker et al, 1995) and changes in cell shape. Because of these diverse functions mediated by $\mathrm{Ca}^{2+}$ in several experimental systems, perhaps including an activation of $\mathrm{K}^{+}$channels, $\mathrm{Ca}^{2+}$ mobilisation has been suggested to be a focus point of cell death, where a variety of apoptosis inducing signals lead to a common death mechanism mediated by $\mathrm{Ca}^{2+}$ signaling (Nicotera et al, 1994a). This theory is supported by several studies, and is further validated by the demonstration that specific inhibitors of the $\mathrm{Ca}^{2+}$-dependent $\mathrm{K}^{+}$channels reduce the extent of apoptotic cell shrinkage (own observations and Beauvais and Dubertret, 1995). Similarly, as discussed earlier, during physiological cell volume regulation, efflux of $\mathrm{K}^{+}$through $\mathrm{Ca}^{2+}$-dependent $\mathrm{K}^{+}$channels as the cell returns to its physiological volume can be inhibited in $\mathrm{Ca}^{2+}$ free medium or by inhibitors of $\mathrm{Ca}^{2+}$-dependent $\mathrm{K}^{+}$channels (own observations and Beauvais and Dubertret, 1995). Together, these studies strongly suggest a role for potassium efflux through $\mathrm{Ca}^{2+}$-activated $\mathrm{K}^{+}$channels as a mediator of apoptotic cell shrinkage in the discussed experimental systems and potentially others.

In conclusion, we have shown that apoptotic associated cell shrinkage is mediated through an active efflux of $\mathrm{Na}^{+}$ and $\mathrm{K}^{+}$ions through the $\mathrm{Na}^{+}, \mathrm{K}^{+}$-ATPase pump and $\mathrm{Ca}^{+}$dependent $\mathrm{K}^{+}$channels, respectively. Inhibition of the $\mathrm{Na}^{+}$, $\mathrm{K}^{+}$-ATPase or $\mathrm{Ca}^{+}$-dependent $\mathrm{K}^{+}$channels prevents apoptosis associated cell shrinkage and subsequent apoptotic body formation independently of both chromatin condensation and internucleosomal DNA fragmentation. Resulting from these observations we propose that apoptotic cell shrinkage is both a regulated and rapid process, which may assist in the rapid removal of apoptotic debris. Further studies will focus on determining the involvement of other ions, in particular $\mathrm{Cl}^{-}$ions, in apoptotic cell shrinkage and in identifying other ionic gradients which are altered during the apoptotic process.

\section{Materials and Methods}

\section{Cell culture and reagents}

Human myeloid HL-60 cells (Collins et al, 1977; Dalton et al, 1988) were grown in RPMI 1640 medium, (Gibco Ltd., Paisley, Scotland), supplemented with $10 \%(\mathrm{w} / \mathrm{v})$ foetal calf serum, (Biochrom KG, Germany), $1 \%$ penicillin and $1 \%$ streptomycin. Cultures were maintained in a humidified incubator at $37^{\circ} \mathrm{C}$ in a controlled $5 \%$ $\mathrm{CO}_{2} / 95 \%$ air atmosphere and were used for experiments during the exponential phase of growth. Ouabain, actinomycin-D, camptothecin, etoposide, Merocyanine 540, DNase-free Ribonuclease A, Proteinase K, PMSF, aprotinin, sodium citrate, dextran, percoll and Anti-mouse IgG peroxidase conjugate were supplied by Sigma Chemical Co. (Dorset, England). Sodium Green, PBFI and Pluronic F-127 were supplied by Molecular Probes (Eugene, OR). Annexin V-FITC was supplied by BRAND Applications BV, Maastricht, The Netherlands, and Anti-sodium/potassium ATPase antibody was supplied by Cymbus Bioscience (Southampton, England).

\section{Induction of apoptosis}

Cells were induced to undergo apoptosis using two previously described strategies, UV-irradiation and cytotoxic stimulation. UVirradiation of cells was carried out as previously described (Martin and Cotter, 1991). Briefly cells $\left(10^{6} / \mathrm{ml}\right)$ were exposed from below to a $302 \mathrm{~nm}$ UV transilluminator source at a distance of $2.5 \mathrm{~cm}$ for $10 \mathrm{~min}$. All UV experiments were conducted in polystyrene culture flasks (Nunc) at room temperature and subsequently cultured for $2-3 \mathrm{~h}$ under standard conditions. Cells were induced to undergo apoptosis in cultures supplemented with $5 \mu \mathrm{g} / \mathrm{ml}$ actinomycin-D, $5 \mu \mathrm{g} / \mathrm{ml}$ camptothecin and $25 \mu \mathrm{g} / \mathrm{ml}$ etoposide over a $4 \mathrm{~h}$ period (Lennon et al, 1991; Martin et al, 1990). 


\section{Assessment of cell viability and morphology}

Prior to experimentation, cell culture densities were determined using an improved Neubauer haemocytometer and culture viability was assessed by their ability to exclude trypan blue. For morphological evaluation of experimental cell populations, cell cytospins were prepared at varying time intervals and stained with RAPI-DIFF ॥ (Diagnostic developments, Southport, UK). Preparations were mounted in DPX mountant (BDH chemicals, Dorset, UK) and percentage apoptosis was determined using previously described criteria (Kerr et al, 1972) under light microscopy.

\section{Cell size and granularity}

Many workers have reported that changes in cell size and buoyant density accompany apoptotic cell death (Martin et al, 1990; Wyllie and Morris, 1982). Thus, cells in early apoptosis will appear smaller and more dense than their normal counterparts. These changes can readily be detected in most cells by their light scattering properties on a flow cytometer (McGahon et al, 1995; Gorman et al, 1996). The light scattering properties (both forward and side scatter), of control and apoptotic cells were analyzed using a FACScan flow cytometer equipped with lysis II software (Becton Dickinson). For all flow cytometry, cells were harvested, washed in pre-heated culture medium and analysed immediately on the flow cytometer. Cells were not fixed.

\section{Membrane lipid-packing}

Merocyanine 540 (MC540) is a naturally fluorescent, lipophylic dye which selectively stains disordered or loosely packed membrane bilayers (Williamson et al, 1983). The method used was adapated from McEvoy et al (1988). Briefly, freshly harvested cells $\left(10^{6}\right)$ were pelleted and re-suspended in $100 \mu \mathrm{l}$ of PBS containing $0.15 \% \mathrm{BSA}(\mathrm{w} /$ v). Stock MC540 (1 mg/ml) was prepared in PBS filter sterilised and stored at $4^{\circ} \mathrm{C}$ in the dark for up to 1 month. Stock MC540 $(8 \mu \mathrm{l})$ was added to the cell suspension, final concentration $80 \mu \mathrm{g} / \mathrm{ml}$. Cell suspensions were incubated at room temperature for $3 \mathrm{~min}$ (no increase in binding was seen after $2 \mathrm{~min}$ ), after which suspensions were diluted in $0.9 \mathrm{ml}$ of PBS containing $0.15 \% \mathrm{BSA}$ and analysed immediately so that the dye was not taken up by endocytosis. For analysis of MC540 the laser was turned to $488 \mathrm{~nm}$ and MC540 was analysed through a $570 \mathrm{~nm}$ long-pass filter (FL-2).

\section{Quantification of phosphatidylserine externalisation on apoptotic cells}

Cells were assayed for binding of annexin $\mathrm{V}$ using a method adapted from Koopman et al (1994). Freshly harvested cells $\left(2 \times 10^{5}\right)$ were removed from culture, centrifuged at normal speed $(200 \mathrm{~g})$, and supernatants were aspirated from the cell pellets. Pellets were then re-suspended in $400 \mu \mathrm{l}$ HEPES buffer $(10 \mathrm{mM}$ HEPES/NaoH, pH 7.4, $150 \mathrm{mM} \mathrm{NaCl}, 5 \mathrm{mM} \mathrm{KCl}, 1 \mathrm{mM} \mathrm{MgCl}$ and $1.8 \mathrm{mM} \mathrm{CaCl} \mathrm{Cl}_{2}$ in $\mathrm{dH}_{2} \mathrm{O}$ ) to which FITC-labelled annexin $\mathrm{V}$ was added, $2.5 \mu \mathrm{g} / \mathrm{ml}$ final concentration. Preparations were incubated at room temperature for $5 \mathrm{~min}$, protected from the light and analyzed immediately by flow cytometry.

\section{DNA isolation and electrophoresis}

DNA was isolated using a method adapted from Swat et al (1991) and detection of internucleosomal DNA fragmentation was performed as previously described (McCarthy et al, 1994).

\section{Western blot analysis}

Whole cell lysates were prepared by solubilising $10^{6}$ cells in $20 \mu$ ice cold suspension buffer [0.1 M NaCl, 0.01 M Tris-Cl (pH 7.6), $0.001 \mathrm{M}$ EDTA (pH 8.0)], $1 \mu \mathrm{g} / \mathrm{ml}$ aprotinin and $100 \mu \mathrm{g} / \mathrm{ml}$ phenylmethylsulfonyl fluoride (PMSF)) and an equal volume of $2 \times$ SDS gel-loading buffer [100 mM Tris-Cl (pH 6.8), $200 \mathrm{mM}$ dithiothreitol, 4\% SDS, $0.2 \%$ bromophenol blue, $20 \%$ glycerol], boiled for $10 \mathrm{~min}$ and loaded on $10 \%$ SDS-polyacrylamide gel, electrophoresed and blotted onto BA85 nitro-cellulose membrane (Schleicher and Schuell Dassel, Germany). After neutralisation with $5 \%$ Blotto ( $5 \%$ non-fat dried milk) in PBS, the membranes were incubated for $2 \mathrm{~h}$ with the anti-Sodium/potassium ATPase monoclonal antibody, diluted $1: 1000$ in $5 \%$ Blotto. Following extensive washing in PBS-Tween, membranes were further incubated with anti-mouse IgM peroxidase conjugate for $1 \mathrm{~h}$, further washed and exposed to auto radiographic film.

\section{Measurement of intracellular free sodium concentrations in cell cultures}

$\left[\mathrm{Na}^{+}\right]_{\mathrm{i}}$ was determined by using the $\mathrm{Na}^{+}$-sensitive dye, $\mathrm{Na}^{+}$-binding Sodium Green ${ }^{\mathrm{TM}}$. The cell permeant Sodium Green tetraacetate, stored at $-20^{\circ} \mathrm{C}$, was slowly thawed to room temperature and then dissolved in DMSO to a stock concentration of $2 \mathrm{mM}$. The nonionic detergent Pluronic F-127 which enhances dye loading was prepared as a $20 \%(\mathrm{w} / \mathrm{v})$ stock solution in DMSO and was added to the dye mixture in a $1: 1$ ratio. Freshly harvested cells $\left(10^{6}\right)$ were washed in HBSS and resuspended at $10^{6} / \mathrm{ml}$ in HBSS supplemented with $5 \mu \mathrm{M}$ sodium green. Cells were incubated with the dye mixture for $30 \mathrm{~min}$ at room temperature, protected from the light. The cells were then washed twice with pre-warmed HBSS to remove extracellular sodium green and analyzed directly by flow cytometry, $488 \mathrm{~nm}$ excitation and $530 \mathrm{~nm}$ emission. Because calibration of Sodium Green fluorescence is cumbersome the data presented in the results section are comparative rather than quantitative in nature.

\section{Measurement of intracellular free potassium concentrations}

The following method was adapted from Barbiero et al (1995). The cell-permeant acetoxymethyl ester (AM) form of the PBFI dye stored at $-20^{\circ} \mathrm{C}$, was slowly thawed to room temperature and dissolved in high quality anhydrous DMSO to a stock concentration of $2 \mathrm{mM}$. The nonionic detergent Pluronic ${ }^{\mathrm{TM}} \mathrm{F}-127$ which enhances dye loading was prepared as a $20 \%(\mathrm{w} / \mathrm{v})$ stock solution in DMSO and was added to the dye mixture in a $1: 1$ ratio. Freshly harvested cells $\left(4 \times 10^{6}\right)$ were washed in RPMI and re-suspended at $4 \times 10^{6} / \mathrm{ml}$ in RPMI supplemented with $10 \mu \mathrm{M} \mathrm{PBFI}$. Cells were incubated with the dye mixture for $60 \mathrm{~min}$ at $37^{\circ} \mathrm{C}$, protected from the light. The cells were then washed once with pre-warmed PBS to remove extracellular PBFI and re-suspended at $2 \times 10^{6} / \mathrm{ml}$ in $10 \mathrm{mM}$ HEPES, pH 7.3, containing $145 \mathrm{mM} \mathrm{NaCl}, 5 \mathrm{mM} \mathrm{KCl}, 1 \mathrm{mM} \mathrm{MgSO}{ }_{4}, 10 \mathrm{mM}$ glucose and $2 \mathrm{mM}$ $\mathrm{CaCl}_{2}$. Cell suspensions were transferred to a quartz cuvette which contained a mini-stirrer, and was placed in a thermostatically controlled $\left(37^{\circ} \mathrm{C}\right)$ quartz cuvette in a Perkin-Elmer LS-5B spectrofluorometer. The AM ester was hydrolysed within the cell to yield the $\mathrm{K}^{+}$-sensitive PBFI free acid form, which exhibited an excitation maximum at $340 \mathrm{~nm}$ and emission maximum at $510 \mathrm{~nm}$.

The ratio of luminescence, obtained by exciting the cells at wavelengths of $340 \mathrm{~nm}$ and $380 \mathrm{~nm}$ while measuring at a constant emission of $510 \mathrm{~nm}$ is indicative of $\left[\mathrm{K}^{+}\right]_{\mathrm{i}}$ due to the observation that the fluorescence of the dye was particularly sensitive to $\left[\mathrm{K}^{+}\right]_{\mathrm{i}}$ when excited at $340 \mathrm{~nm}$, yet was relatively unaffected when excited at $380 \mathrm{~nm}$. PBFI 
fluorescence as a function of $\left[\mathrm{K}^{+}\right]_{\mathrm{i}}$ was calibrated in situ with cells bathed in medium of known $\left[\mathrm{K}^{+}\right]$, prepared by mixing different amounts of two solutions of equal ionic strength: one potassium free, containing $100 \mathrm{mM}$ sodium gluconate and $30 \mathrm{mM} \mathrm{NaCl}$, the other containing $100 \mathrm{mM}$ potassium gluconate and $30 \mathrm{mM} \mathrm{KCl}$. Both solutions contained $10 \mathrm{mM}$ HEPES, $2 \mathrm{mM} \mathrm{CaCl}_{2}$ and $1 \mathrm{mM} \mathrm{MgSO}_{4}$. The 340/ $380 \mathrm{~nm}$ ratio was determined before and $3 \mathrm{~min}$ after addition of gramicidin-D (1 $\mu \mathrm{M}$ final concentration) and valinomycin ( $2 \mu \mathrm{M}$ final concentration).

\section{Acknowledgements}

We are particularly grateful to Afshin Samali for providing Figure 1A. We would also like to thank Prof. Brian Harvey, Prof. Chris Haslett and Dr. lan Dransfield, for technical assistance and discussion, and Dr. Susan Adams and Dr. Maureen O'Sullivan for bleeding volunteers. This work was supported by a grant from the Irish Cancer Society and EU Biomedical Programme.

\section{References}

Anderson-Lobaugh L and Liberman M (1987) Na-K pump site density and ouabain binding affinity in cultured chick heart cells. Am. J. Physiol. 253: 731-743

Arends MJ and Wyllie AH (1991) Apoptosis: mechanisms and role in pathology. Int. Rev. Exp. Pathol. 32: 223-254

Barbiero G, Duranti F, Bonelli G, Amenta JS and Baccino FM (1995) Intralcellular ion variations in the apoptotic death of $L$ cells by inhibition of cell cycle progression. Exp. Cell. Res. 217: 410-418

Beauvais F, Michel L and Dubertret L (1995) Human esoinophils in culture undergo a striking rapid shrinkage during apoptosis. Role for $\mathrm{K}^{+}$channels. J. Leuk. Biol. 57: $851-855$

Beavers EM, Comfurius P, Van Rijn JL, Hemker HC and Zwaal RFA (1982) Generation of prothrombin-converting activity and the exposure of phosphatidylserine at the outer surface of platelets. Eur. J. Biochem. 122: 429-436

Bertorello AM, Aperia A, Walaas SI, Nairn AC and Greengard P (1991) Phosphorylation of the catalytic subunit of $\mathrm{Na}^{+}, \mathrm{K}^{+}$-ATPase inhibits the activity of the enzyme. Proc. Natl. Acad. Sci. USA 88: 11359-11362

Bonyhadi M, Rabin L, Salimi S, Brown DA, Kosek J, McCune JM and Kaneshima H (1993) HIV induces thymus depletion in vivo. Nature 363: 728-732

Bowen ID and Bowen SM (1990) Programmed cell death in tumours and tissues. Chapman and Hall, London

Cahalan MD and Lewis RS (1988) Role of potassium and chloride channels in volume regulation by T lymphocytes. In: Cell Physiol. of Blood. Edited by Gunn RB and Parker JC. NY Rockfeller Univ. Press, pp 281

Cohen GM, Sun X-M, Snowden RT, Dinsdale D and Skilleter DN (1992) Key morphological features of apoptosis may occur in the absence of internucleosomal DNA fragmentation. Biochem J. 286: 331 -334

Collins SJ, Gallagher RE and Gallo RC (1977) Continuous growth and differentiation of human myeloid cells in suspension culture. Nature 270: 347-349

Cotter TG, Lennon SV, Glynn JM and Green DR (1992) Microfilament-disrupting agents prevent the formation of apoptotic bodies in tumour cells undergoing apoptosis. Cancer Res. 52: 997-1005

Dalton WT, Ahearn MJ, McCredie K, Freidreich EJ, Stass SA and Trujilio JM (1988) $\mathrm{HL}-60$ cell line was derived from a patient with FAB-M2 and not FAB-M3. Blood $71: 242-247$

Dransfield I, Buckle AM, Savill JS, McDowall, Haslett C and Hogg N (1994) Neutrophil apoptosis is associated with a reduction in CD16 (FcyRIII) Expression J. Immunol. 153: 1254-1263

Ellis RE, Yuan L and Horvitz HR (1991) Mechanisms and functions of cell death. Ann. Rev. Cell. Biol. 7: 663-698

Fadok VA, Lazslo DJ, Noble PW, Weinstein L, Riches DWH and Henson PM (1993) Particle digestibility is required for induction of phosphatidylserine recognition mechanism used by murine macrophages to phagocytose apoptotic cells. J. Immunol. 151: $4274-4285$
Fadok VA, Savill JS, Haslett C, Bratton DL, Doherty DE, Campbell PA and Henson PM (1992b) Different populations of macrophages use either the vitronectin receptor or the phosphatidylserine receptor to recognise and remove apoptotic cells. J. Immunol. 149: 4029-4035

Fadok VA, Voelker DR, Campbell PA, Cohen JJ, Bratton DL and Henson PM (1992a) Exposure of phosphatidylserine on the surface of apoptotic lymphocytes triggers specific recognition and removal by macrophages. J. Immunol. 148:2207-2216

Frizzell RA, Rechkemmer G and Shoemaker RL (1986) Altered regulation of airway epithelial cell chloride channels in cystic fibrosis. Science 233: $558-560$

Gallin EK (1991) Ion channels in leukocytes. Physiol. Rev. 71: 775-789

Glynn IM (1985) The $\mathrm{Na}^{+}, \mathrm{K}^{+}$, transporting adenosine triphosphate, P. $35-144$. In: The enzymes of biological membranes, Vol. 3, 2nd ed. Martonosi A (ed.), Plenum Publishing Corp., New York

Gorman A, McCarthy JV, Finnucane D, Reville W and Cotter TG (1996) Morphological Aspects of Apoptosis and Necrosis. In: Techniques in Apoptosis: A User's Guide. TG Cotter and SJ Martin (editors). Portland Press Ltd., UK

Grinstein S, Rothstein B, Sarkadi B and Gelfand EW (1984) Responses of lymphocytes to anisotonic media: Volume regulating behaviour. Am. J. Physiol. 264: $204-215$

Hallbrucker C, vom DahI S, Lang F, GerokW and Häussinger D (1991) Modification of liver cell volume by insulin and glucagon. Pfugers Arch. 481: 519-521

Hallow KR, Packman CH and Knauf PA (1991) Acute cell volume changes in anisotontic media affect F-actin content of HL-60 cells. Am. J. Physiol. 261: $1154-1161$

Hazama A and Okada Y (1988) $\mathrm{Ca}^{2+}$ sensitivity of volume regulatory ion $\mathrm{K}$ and $\mathrm{cl}$ channels in cultured human epithelial cells. J. Physiol. 402: 687-702

Hoffmann EK (1985) Volume dependent $\mathrm{NaCl}$ cotransport and volume induced increase in $\mathrm{K}^{+}$and $\mathrm{Cl}^{+}$permeability in Echrlich cells. Federation Proc. 44:25132519

Hoffman EK and Simonsen LO (1989) Membrane mechanisms in volume and pH regulation in vertebrate cell. Physiol. Rev. 69 : 315-382

ljiri K and Potten CS (1987) Further studies on the response of intestinal cells of different hierarchial status to eighteen different cytotoxic agents. Br. J. Cancer 55: $113-123$

Kerr JFR, Harmon B and Searle J (1974) An electron microscope study of cell delection in the anuran tail during spontaneous metamorphosis with special reference to apoptosis in striated muscle fibers. J. Cell Sci. 14: 571-575

Kerr JFR, Wyllie AH and Currie AR (1972) A basic biological phenomenon with wideranging implications in tissue kinetics. Br. J. Cancer 26: 239-257

Kizaki H, Shimada H, Ohsaka F and Sakurada T (1988) Adenosine, deoxyadenosine and deoxyguanosine induce DNA cleavage. J. Immunol. 141: 1652-1657

Lande MB, Donovan JM and Zeidel ML (1995) The relationship between membrane fluidity and permeabilities to water, solutes, ammonia and proteons. J. Gen. Physiol. 106: 67-84

Lee CO (1988) 200 years of digitalis: the emerging central role of the sodium ion in the control of cardiac force. Am. J. Physiol. 249: 367-378

Lennon SV, Martin SJ and Cotter TG (1991) Induction of apoptosis (programmed cell death) in tumour cells by widely diverging stimuli. Cell Prolif. 24: 203-214

Lichtman MA, Jackson AH and Oeck WA (1972) Lymphocyte monovalent ion metabolism: cell volume, cation content and cation transport. J. Cell Physiol. 80: 383-396

Lockshin R, Alles A, Kodaman N and Zakeri ZF (1991) Programmed cell death and apoptosis: early DNA degradation does not appear to be prominant in either embryonic cell death or metamorphosis of insects. FASEB J. 5: A518-525

Lockshin RA and Zakeri-Milovanovic Z (1994) Nucleic acids in cell death. In Cell aging and cell death (eds. Davies I and Sigee DC) pp. 243-268. Cambridge University Press, Cambridge, UK

Macknight ACD (1988) Principles of cell volume regulation. Renal Physiol. Biochem. 11: $114-141$

Martin SJ and CotterTG(1991a) Disruption of microtubules induces an endogeneous cell suicide pathway in human leukemia HL-60 cells. Cell Tissue Kinet. 23:545559

Martin SJ and Cotter TG (1991) Ultraviolet B irradiation of human leukemia HL-60 cells in vitro induces apoptosis. Int. J. Radiat. Biol. 59: 1001-1016

Martin SJ, Bradley JG and Cotter TG (1990) HL-60 cells induced to differentiate towards neutrophils subsequently die via apoptosis. Clin. Exp. Immunol. 79 : $448-453$ 
Martin SJ, Reutelingsperger CPM, McGahon A, Radar JA, van Schie RC, la Face D and Green DR (1995) Early redistribution of plasma membrane phosphatidylserine is a general feature of apoptosis regardless of initiating inhibition by over-expression of Bcl-2 and Abl. J. Exp. Med. 182: 1545-1556

McCarthy JV, Fernandes RS and Cotter TG (1994) Increased resistance to apoptosis associated with HL-60 myeloid differentiation status. Anticancer Res. 14:20632072

Morris RG, Duvall E, Hargreaves AD and Wyllie AH (1984) Hormone induced cell death. 2. Changes in the cell surface of apoptotic thymocytes. Am. J. Pathol. 115: $426-436$

Nicotera P, Zhivotovsky B and Orrenius S. (1994b) Cell Calcium 16: 279-288

Nicotera P, Zhivotovsky B, Bellomo G and Orrenius S. (1994a) lon signalling in apoptosis. In: Apoptosis. Schimke RT, Mihich E (eds). New York, Plenum Press pp 97

Op den Camp JAF (1979) Lipid asymmetry in membranes. Ann. Rev. Biochem. 48: $47-71$

Raff MC (1992) Social controls on cell survival. Nature 356: 397-400

Rosing J, Van Rijn JL, Bevers EM, Van Dieijen G, Comfurius P and Zwaal RFA (1985) The role of activated human platelets in prothrombin and factor $X$ activation. Blood 65: 319-332

Savill JS, Wyllie AH, Henson JE, Walport MJ, Henson PM and Haslett C (1989) Macrophage phagocytosis of ageing neutrophils in inflammation. Programmed cell death in the neutrophil leads to its recognition by macrophages. J. Clin. Invest. 83: 865-875

Schlegel RA, Stevens M, Lumley-Sapanski K and Milliamson P (1993) Altered lipid packing identifies apoptotic tymocytes. Immunol. Lett. 36: 283-288

Schwartz W and Passow H (1983) $\mathrm{Ca}^{2+}$ activated $\mathrm{KI}^{+}$channels in erythrocytes and excitable cells. Ann. Rev. Physiol. 45: 359-374
Shi Y, Glynn JM, Guilbert LJ, Cotter TG, Bissonnette RP and Green DR (1992) Role for c-myc in activation-induced apoptotic cell death in T cell hybridomas. Science 257: $212-214$

Simchowitz L, Spilberg I and De Weer P (1982) Sodium and potassium fluxes and membrane potential of human neutrophils. J. Gen. Physiol. 79: 453-479

Swat W, Ignatowicz L and Kieslow P (1991) Detection of apoptosis of immature $\mathrm{CD}^{+}{ }^{+} \mathrm{CD} 8^{+}$thymocytes by flow cytometry. J. Immunol. Methods. 137: 79-87

Thomas N and Bell PA (1981) Glucocorticoid-induced cell size changes and nuclear fragility in rat thymocytes. Mol. Cell Endocrinol. 22: 71-84

Trump BF, Berezesky IK and Phelps PC (1981) Sodium and calcium regulation and the role of the cytoskeleton in the pathogenesis of disease: a new hypothesis. Scann. Electron Micros. 2: 437-462

Walker PR, Pandey S and Sikorska M (1995) Degradation of chromatin in apoptotic cells. Cell Death Differ. 2: $97-104$

Williamson P, Mattocks K and Schlegel RA (1983) Merocyanine 540, a fluorescent probe sensitive to lipid packing. Biochim. Biophys. Acta. 732: 387-393

Woll E, Ritter M, Scholz W, Haussinger D and Lang F (1993) The role of calcium in cell shrinkage and intracellular alkinization by bradykinin in Ha-ras oncogene expressing cells. FEBS Lett. 332: 261-265

Wyllie AH (1987) Apoptosis: Cell death in tissue regulation. J. Pathol. 153: 313-316

Wyllie AH (1993) The Frank Rose Memorial Lecture. Br. J. Cancer 67: 205-208

Wyllie AH and Morris RG (1982) Hormone induced cell death: purification and properties of thymocytes undergoing apoptosis after glucocorticoid treatment. Am. J. Pathol. 109: 80-84

Zhu W, Murtha PE and Toung CYF (1995) Calpain inhibitor-induced apoptosis in human prostate adenocarcinoma cells. Biochem. Biophys. Res. Comm. 214: $1130-1137$ 